\title{
Regulation of NKT cell localization in homeostasis and infection
}

\author{
Drew Slauenwhite $^{1}$ and Brent Johnston ${ }^{1,2,3,4 *}$ \\ ${ }^{1}$ Department of Microbiology and Immunology, Dalhousie University, Halifax, NS, Canada, ${ }^{2}$ Department of Pediatrics, \\ Dalhousie University, Halifax, NS, Canada, ${ }^{3}$ Department of Pathology, Dalhousie University, Halifax, NS, Canada, ${ }^{4}$ Beatrice \\ Hunter Cancer Research Institute, Halifax, NS, Canada
}

Natural killer T (NKT) cells are a specialized subset of T lymphocytes that regulate immune responses in the context of autoimmunity, cancer, and microbial infection. Lipid antigens derived from bacteria, parasites, and fungi can be presented by CD1d molecules and recognized by the canonical T cell receptors on NKT cells. Alternatively, NKT cells can be activated through recognition of self-lipids and/or pro-inflammatory cytokines generated during infection. Unlike conventional T cells, only a small subset of NKT cells traffic through the lymph nodes under homeostatic conditions, with the largest NKT cell populations localizing to the liver, lungs, spleen, and bone marrow. This is thought to be mediated by differences in chemokine receptor expression profiles. However, the impact of infection on the tissue localization and function of NKT remains largely unstudied. This review focuses on the mechanisms mediating the establishment of peripheral NKT cell populations during homeostasis and how tissue localization of NKT cells is affected during infection.

Keywords: natural killer T cells, chemokines, cytokines, homeostasis, leukocyte homing

\section{Introduction}

The clearance of bacterial, viral, fungal, and protozoan infections depends upon the coordinated activation of both the innate and adaptive arms of the immune system (1). Innate immune cells, such as macrophages, dendritic cells (DCs), neutrophils, and natural killer (NK) cells, are critically involved in the initial control and clearance of infectious organisms. However, adaptive immunity mediated by $\mathrm{T}$ cells and $\mathrm{B}$ cells is also required to generate specific sterilizing responses and provide long-lasting immunological memory. Natural killer T (NKT) cells are a subset of T cells that serve as a bridge between innate and adaptive immunity. Upon activation, NKT cells rapidly generate and secrete a diverse array of cytokines and chemokines (2-4), allowing them to shape the magnitude and polarization of host immune responses in infection $(5,6)$, autoimmune disease $(7,8)$, allergy $(9$, 10), and cancer (11). Compared to conventional T cells, NKT cells exhibit altered patterns of tissue localization, suggesting differences in the signals regulating homing and homeostasis. This review examines pathways important in the trafficking and maintenance of NKT cell populations under homeostatic conditions and during microbial infections. The impact of these mechanisms on NKT cell-derived anti-microbial effector functions will be discussed in terms of their ability to orchestrate both innate and adaptive immune responses.

\section{Natural Killer T Cells}

Natural killer T cells develop in the thymus from uncommitted thymic progenitors that undergo T cell receptor (TCR) rearrangement and selection. However, unlike the diverse TCR repertoire of conventional $\mathrm{T}$ cells that are selected via type I or type II major histocompatibility complex 
(MHC), NKT cells express a restricted repertoire of TCR rearrangements that are selected via the MHC-like molecule CD1d (12, 13). While the specific selecting antigen(s) in the thymus remains unclear, several endogenous NKT cell ligands have been proposed based on NKT cell activating capacity. These include isoglobotrihexosylceramide (iGb3) (14), lysophosphatidylcholine (LPC) and lysosphingomyelin (LSM) (15), the peroxisome-derived ether-bonded compounds lysophosphatidylethanolamine (pLPE) and lysophosphatidic acid (eLPA) (16), $\beta$-glucosylceramide ( $\beta$-GluCer) (17), and $\alpha$-glycosylceramides (18). However, the relative roles of these candidate ligands during intrathymic NKT cell development in mouse versus human as well as their capacities to influence NKT cell functional regulation and/or tissue localization in the periphery remain undefined.

Isoglobotrihexosylceramide, which appeared to be a promising candidate for an endogenous NKT cell selecting antigen in mice, is unlikely to be an endogenous ligand for human NKT cells due to the lack of the relevant iGb3 synthase enzymes in humans (19). Furthermore, the contamination of commercial $\beta$-GluCer with $\alpha$-linked species has brought into question the role of this compound. Indeed, two groups have demonstrated that highly purified preparations of $\beta$-GluCer lack NKT cell stimulatory activity $(18,20)$. However, Kain and colleagues (18) identified the presence of small quantities of endogenous $\alpha$-linked glycosylceramides [ $\alpha$-GluCer and $\alpha$-galactosylceramide ( $\alpha$-GalCer)], a class of glycolipids that were thought to be absent in mammalian cells, and identified them as possible endogenous ligands for NKT cell selection and activation. Our understanding of NKT cell development and function will continue to improve as ongoing efforts further characterize the self-lipid antigens that select NKT cells in the thymus.

Two major subsets of NKT cells can be distinguished based on their TCR repertoire and lipid reactivity. Type I or invariant NKT $(i \mathrm{NKT}$ ) cells express an invariant TCR $\alpha$ chain composed of $\mathrm{V} \alpha 14-\mathrm{J} \alpha 18$ rearrangements in mice and $\mathrm{V} \alpha 24-\mathrm{J} \alpha 18$ in humans, paired with a restricted repertoire of $\mathrm{V} \beta$ chains $(\mathrm{V} \beta 8.2, \mathrm{~V} \beta 7$, or $\mathrm{V} \beta 2$ in mice, and V $\beta 11$ in humans) $(21,22)$. Specific detection of $i$ NKT cells is possible through the use of CD1d tetramers loaded with $\alpha$-GalCer $(23,24)$. Analogs of $\alpha$-GalCer are potent activators of $i$ NKT cells and can influence immune responses in many pathological states, including microbial infection $(25,26)$, autoimmune disease (7), allergy (27), and cancer (28). Type II NKT cells are CD1d-restricted but do not recognize $\alpha$-GalCer (29). This is a more heterogeneous population of cells, expressing oligoclonal TCRs that utilize a limited collection of $\mathrm{V} \alpha(\mathrm{V} \alpha 1, \mathrm{~V} \alpha 3, \mathrm{~V} \alpha 8)$ and V $\beta$-rearrangements (29-31). Comparisons of $\mathrm{J} \alpha 18^{-/-}$mice lacking type I NKT cells with CD1d $\mathrm{d}^{-/-}$mice lacking type I and type II NKT cells suggest that the type II NKT cells are regulatory cells that can suppress anti-tumor immunity (32-34). The best characterized subset of type II NKT cells expresses a TCR that recognizes sulfatide (3-sulfated galactosylceramide) $(29,31,35)$. These cells serve as an important regulatory population during inflammatory responses and can be activated by sulfatide to suppress autoimmunity (36-40). Type II NKT cells can also regulate $i$ NKT cell responses. For example, activation of type II NKT cells by sulfatide suppresses the proliferative and cytokine responses of $i$ NKT cells activated with $\alpha$-GalCer (33). Furthermore, in a ConAinduced hepatic injury model, sulfatide-activated type II NKT cells induced $i$ NKT cell anergy and prevented inflammatory liver disease (37). However, dysregulated responses of type II NKT cells have also been shown to play a role in the pathogenesis of inflammatory bowel disease in both mice and humans $(41,42)$. While $i$ NKT cells are more prevalent than type II NKT cells in mice, type II NKT cells appear to be the predominant subset in humans (43). This review focuses on responses of $i$ NKT cells, and the term NKT cell will be used throughout to refer to this population.

In addition to TCR-CD1d interactions, NKT cells are also stimulated by inflammatory cytokines (44-46), neurotransmitters (47), and toll-like receptor (TLR) ligands (48-50). Following activation, NKT cells are able to produce a wide range of cytokines including interferon- $\gamma($ IFN- $\gamma)$, tumor necrosis factor (TNF), interleukin-2 (IL-2), IL-4, IL-10, IL-13, IL-17, IL-21, IL22 , and granulocyte-macrophage colony-stimulating factor (GMCSF) $(2-4,51)$. However, the cytokine profile is influenced by the nature of the stimulation and the subset of NKT cells that are activated. Indeed, recent studies have identified a number of distinct lineages of NKT cells that emerge during development, each with a unique profile of transcription factors and cytokine production (52-59). Based on these profiles, NKT cells can be subdivided into NKT-1, NKT-2, NKT-17, and NKT-10 subsets, analogous to the T helper type 1 (Th1), Th2, Th17, and IL-10 producing subsets of conventional T cells. Through their secretion of various cytokines, NKT cells are able to activate other immune cells, contributing to NK cell transactivation (60), DC maturation $(61,62)$, T cell polarization $(63,64)$, and B cell antibody responses $(65)$.

\section{NKT Cell Homeostasis}

Natural killer $\mathrm{T}$ cells require a number of growth factors and survival signals for their maintenance in the periphery. In contrast to the requirement for CD1d during thymic NKT cell selection and initial maturation, mature NKT cells do not require continual CD1d interactions in the periphery to support homeostatic proliferation, long-term survival, or to maintain tissue distribution (66). Instead, NKT cells rely more on signaling elicited by cytokines such as IL-15, and to a lesser extent IL-7 (66-69). However, while thymic NKT cell development and homeostatic NKT cell proliferation are impaired in IL-15-deficient mice, these populations are not abolished $(67,70)$. It is possible that this is due to differences in the requirement for IL-15 during development of distinct NKT cell lineages. For example, NKT-1 cells express CD122 (the IL2/IL-15 receptor $\beta$-chain) and require IL- 15 for development and homeostasis, while NKT-2/NKT-17 cells (marked by the expression of IL-17RB, a receptor for IL-25) develop normally in the absence of IL-15 (58). Accordingly, CD122 is moderately to highly expressed on NKT cells in the mouse liver and spleen, where the NKT-1 lineage constitutes the majority of the NKT population, but is not expressed on lymph node NKT cells, where NKT-17 cells are enriched $(52,54)$. ICOS/ICOSL interactions are also required for NKT cell homeostasis and function as survival of wild-type NKT cells transferred into $\mathrm{ICOSL}^{-1-}$ mice was reduced, and ICOS $^{-1-}$ NKT cells were impaired in their ability to produce IL-4 and IL-13 (71). Many studies have highlighted roles for a 
variety of signaling molecules and transcription factors in NKT cell development and homeostasis, including NF- $\mathrm{KB}$ (72), T-bet $(73,74)$, c-Myc $(75,76)$, mTORC2 (77), calcineurin (78), Egr2 (78), Id2 (79), Bcl-2 (80), Bcl- $\mathrm{X}_{\mathrm{L}}(81)$, in addition to cytokine receptor subunits IL-2R $\beta$ (82), IL-7R $\alpha$ (83), IL-15R $\alpha(84,85)$, and the common gamma chain (83).

In addition to these factors, chemokine receptor signaling has also been implicated in regulating NKT cell homeostasis in the periphery. NKT cells express high levels of CXC chemokine receptor 6 (CXCR6) (86-89), and NKT cells in the liver and lungs are depleted in mice lacking CXCR6 or its ligand CXCL16 (90-92). Geissmann et al. (90) reported that NKT cells from $\mathrm{CXCR}^{-1-}$ mice underwent apoptosis more rapidly in culture than NKT cells from $\mathrm{CXCR6}^{-1+}$ mice. In vivo however, $\mathrm{CXCR}^{-1-}$ and $\mathrm{CXCR}^{-1+}$ mice exhibited a similar frequency of apoptotic CD1d-reactive cells in liver sections and freshly isolated liver lymphocytes (90). We found no difference in the apoptosis rates of cultured NKT cells purified from the livers of $\mathrm{CXCR6}^{+/+}$and $\mathrm{CXCR6}^{-1-}$ mice (91), but observed an accumulation of NKT cells in the bone marrow, suggesting an alteration in homing. Interestingly, mice deficient in Id2 exhibit impaired survival of liver NKT cells, which is associated with reduced expression of CXCR6 and the survival factors Bcl-2 and Bcl-X $\mathrm{L}_{\mathrm{L}}$ (79). Similarly, hepatic NKT cells from CXCR6-deficient mice expressed lower levels of $\mathrm{Bcl}-2$, suggesting a role in survival (79). Despite the conflicting reports, it seems likely that CXCR6 plays a role in regulating survival of NKT cells within certain tissue environments [since NKT cell numbers are normal in most tissues (90-92)], or under specific culture conditions.

A separate study found that NKT cells in CC chemokine receptor 5 (CCR5)-deficient mice were resistant to activation-induced apoptosis, and produced more IL-4, resulting in enhanced liver injury in a model of ConA-induced hepatitis (93). Interestingly, despite an impairment of activation-induced cell death, there were no defects in Fas-mediated apoptosis in these NKT cells. In human T cells, CCR5-dependent apoptosis has been reported in response to high concentrations of the chemokine ligand CCL5 (94), or ligation of CCR5 by the human immunodeficiency virus (HIV) envelope protein gp160 (95). In these cases however, there was enhanced susceptibility to caspase-8-dependent cell death through induction of FasL (95). These studies point to a role for chemokine receptors in influencing lymphocyte survival and add to a growing body of literature demonstrating the ability of chemokine receptors to regulate a number of cellular functions in addition to their traditional roles in regulating leukocyte recruitment and positioning.

Natural killer T cell homeostasis is also regulated by the microbiome. Germ-free Swiss-Webster and C57BL/6 mice exhibit variable alterations in thymic, spleen, and liver NKT cell populations compared to conventionally housed animals (96-98). This variability may reflect differences in the conventional microbiota in control mice housed in different facilities (98). However, germfree mice consistently exhibited increased numbers of NKT cells in the intestinal lamina propria and lungs $(96,98)$. NKT cell accumulation appears to result from dysregulated CXCL16 expression, and could be reversed by CXCL16 blockade or neonatal exposure to conventional microbiota (96). Bacteria of the genera Bacteroides comprise $>50 \%$ of the bacteria in the human gut (99), and $B$. fragilis has been shown to generate $\alpha$-GalCer derivatives capable of regulating NKT cells $(100,101)$. One such compound, $\alpha-$ GalCer $_{\mathrm{Bf}}$, binds to CD1d and activates NKT cells in vitro and in vivo, albeit to a lesser degree than synthetic $\alpha$-GalCer (100). However, colonization of germ-free mice with $B$. fragilis led to variable expansion of NKT cells (100). B. fragilis also generates GSL-Bf717, an $\alpha$-GalCer analog that inhibits NKT cell activity and restored NKT cell homeostasis in germ-free mice (101). Therefore, it appears that the composition of the intestinal microbiota influences the homeostasis of NKT cells within the colon and lungs, and may also exert influences on NKT cells within other tissues. Adding further complexity, NKT cells also influence bacterial colonization in the intestine (102), and engagement of epithelial CD1d contributes to intestinal epithelial cell-dependent regulation of mucosal homeostasis via IL-10 production (103), highlighting the intricate interactions which take place between host cells and the microbiota.

\section{NKT Cell Tissue Localization Patterns}

In mice, NKT cells are first detected in the thymus at day 5-6 after birth, and in the periphery after day $8(12,104)$. They populate multiple tissues and reach steady state levels by 5-6 weeks of age. In the adult mouse, NKT cell frequency is highest in the liver (12-30\% of liver lymphocytes), with lower frequencies in the spleen $(1-3 \%)$, lungs $(5-10 \%)$, thymus $(0.5-1 \%)$, bone marrow $(0.4-8 \%)$, lymph nodes $(0.2-1 \%)$, intestines $(0.05-0.6 \%)$, and blood $(0.2 \%)(23,24,98,105-110)$.

In contrast to the post-natal NKT cell ontogeny in mice, NKT cells are detected in the human fetal thymus at the start of the second trimester, but the frequency declines with gestational age to reach low levels in the post-natal thymus $(111,112)$. Human NKT cells also distribute to the periphery during the second trimester, with a prominent distribution to the small intestine which may act as a maturation site (113). Overall, the tissue distribution of NKT cells in the periphery appears to be similar between adult humans and mice. However, the frequency of NKT cells in humans is significantly lower and is subject to considerable variability among individuals. For example, frequencies of NKT cells range from 0.05 to $1 \%$ of liver lymphocytes in humans (114, 115 ), and generally account for $0.01-0.1 \%$ of human peripheral blood mononuclear cells, but have been observed to constitute upwards of $3 \%$ of peripheral blood mononuclear cells in some individuals $(112,116-118)$. The variability in NKT cell frequency between individuals appears to be influenced by genetic factors as evidenced by identical twin studies (118). Despite these differences, NKT cells play important roles in human health and disease. Indeed, dysfunctional NKT cell responses and reduced circulating numbers of NKT cells have been reported in patients with autoimmune disorders (8) and malignancies (119-122), suggesting a role for NKT cells in maintaining immune homeostasis.

\section{Phenotypic and Functional Differences in NKT Cell Subsets}

Even though NKT cells have a restricted TCR profile, they contain phenotypically and functionally diverse subpopulations characterized by differences in surface marker expression, tissue 
TABLE 1 | Chemokine receptor expression and ligand responses on circulating human NKT cells.

\begin{tabular}{|c|c|c|c|c|c|}
\hline \multirow[t]{2}{*}{ Receptor } & \multicolumn{3}{|c|}{ Expression (\%) ${ }^{\mathrm{a}}$} & \multirow{2}{*}{$\begin{array}{l}\text { Chemotactic } \\
\text { response }^{c}\end{array}$} & \multirow[t]{2}{*}{ Reference } \\
\hline & $\mathrm{CD}^{+}$ & $\mathrm{DN}^{\mathrm{b}}$ & $\mathrm{CDB}^{+}$ & & \\
\hline $\mathrm{CCR} 1^{d}$ & $2-25$ & $55-85$ & $30-80$ & $\begin{array}{l}\mathrm{CD}^{+} ; \mathrm{DN}^{++} \\
\mathrm{CD} 8^{++}\end{array}$ & $(87,89)$ \\
\hline $\mathrm{CCR}^{\mathrm{d}}$ & $60-80$ & $95-99$ & $65-99$ & +++ & $(87,89)$ \\
\hline CCR3 & $0-4$ & $0-4$ & $0-4$ & n.d. & $(87,89)$ \\
\hline CCR4 & $12-40$ & $4-18$ & $2-10$ & $\begin{array}{l}\mathrm{CD}^{++}{ }^{+} ; \mathrm{DN}^{+} ; \\
\mathrm{CD} 8^{-}\end{array}$ & $(87,89)$ \\
\hline CCR5 & $45-80$ & 90-99 & 70-99 & + & $(4,87,89,116)$ \\
\hline CCR6 & $10-68$ & $72-95$ & $50-85$ & $\begin{array}{l}\mathrm{CD}^{+} ; \mathrm{DN}^{+++} \\
\mathrm{CD}^{+++}\end{array}$ & $(87,89,116)$ \\
\hline CCR7 & $11-28$ & $7-32$ & $2-25$ & ++ & $(4,87,89)$ \\
\hline CCR8 & \multicolumn{3}{|c|}{$11-55 \%$ total NKT cells } & - & $(89,140)$ \\
\hline CCR9 & $0-4$ & $0-4$ & $0-4$ & - & $(87,89)$ \\
\hline CCR $10^{e}$ & n.d. & n.d. & n.d. & - & (89) \\
\hline CXCR1 & $5-10$ & $3-8$ & n.d. & - & (89) \\
\hline CXCR2 & $0-2$ & $0-1$ & n.d. & - & (89) \\
\hline CXCR3 & $75-90$ & $95-99$ & $80-90$ & +++ & $(4,87,89)$ \\
\hline CXCR4 & $90-99$ & $98-99$ & $95-99$ & +++ & $(4,87,89)$ \\
\hline CXCR5 & $0-4$ & $0-4$ & $0-4$ & - & $(87,89)$ \\
\hline CXCR6 & $22-45$ & $85-99$ & $60-98$ & ++ & $(87,89,116)$ \\
\hline $\mathrm{CX}_{3} \mathrm{CR} 1$ & $4-12$ & $4-12$ & n.d. & - & (89) \\
\hline
\end{tabular}

${ }^{a}$ Range in reported frequency of receptor positive NKT cells.

${ }^{b} \mathrm{DN}=\mathrm{CD} 4^{-} \mathrm{CD} 8^{-}$double negative NKT cells.

${ }^{c}$ Net chemotactic migration: - (did not respond), $+(2-10 \%),++(11-30 \%)$, and +++ (>30\%)

dOthers report CCR1 and CCR2 on $<2 \%$ of NKT cells $(89,116)$.

${ }^{e}$ CCR8 and CCR10 mRNA detected in NKT cell subsets (89).

n.d. - not determined.

localization, and effector functions. NKT cells in humans can be divided into $\mathrm{CD}^{+}$(12-36\%), $\mathrm{CD}^{-}{ }^{-} \mathrm{CD} 8^{-}$(DN; 60-85\%), or $\mathrm{CD}^{-}{ }^{-} \mathrm{CD} 8 \alpha^{+}(1-5 \%)$ subsets (123). While the DN and CD8 $\alpha^{+}$ subsets in human blood are phenotypically and functionally similar, the $\mathrm{CD}^{+}{ }^{+}$subset represents a functionally distinct lineage with marked differences in cytokine profile and homing receptor expression (see Table 1) $(4,87,116)$. For example, CD $4^{-}$NKT cells produce primarily Th1 cytokines such as IFN- $\gamma$ and TNF, while $\mathrm{CD}^{+}$NKT cells generate both Th1 and Th2 cytokines (IFN- $\gamma$, TNF, IL-4, IL-5, IL-10, and IL-13) (4, 87, 116). However, tissue-resident NKT cells may have differences in surface marker expression and cytokine profiles $(115,124)$.

Natural killer T cells in mice are comprised of CD4 ${ }^{+}(60-80 \%$, depending on the tissue) and DN subsets, while $\mathrm{CD} 8^{+} \mathrm{CD} 1 \mathrm{~d}-$ restricted NKT cells are absent $(24,105,125)$. A Th2-like subset of $\mathrm{CD}^{+}{ }^{+}$NKT cells localizes to the lungs and contributes to airway hyperreactivity and asthma $(126,127)$, while a subset of DN IL17-producing NKT cells localize preferentially to the lymph nodes and skin (54). Although there is little evidence for differences in cytokine profiles of $\mathrm{CD}^{+}$and DN NKT cell subsets in the liver and spleen, functional differences have been reported. For example, DN NKT cells from the liver are able to control tumors better than $\mathrm{CD}^{+}{ }^{+} \mathrm{NKT}$ cells from the liver or NKT cells from other tissues (128). NKT-1, NKT-2, NKT-10, NKT-17, and follicular helper-type NKT $\left(\mathrm{NKT}_{\mathrm{FH}}\right)$ subsets of NKT cells have recently been identified on the basis of transcription factor profiles and select surface marker expression (52-59, 129). However, more work is needed to determine the maintenance and plasticity of these profiles since the population ratios in mice seem to change significantly over time (55). Although NKT-1, NKT-2, and NKT17 subsets emerge in the thymus, it is likely that tissue-specific factors and microenvironmental influences act to shape the phenotype and function of NKT cells after recruitment to specific tissue sites.

\section{Expression of Homing Receptors on NKT Cells}

The trafficking behaviors of naïve and effector/memory lymphocyte subsets are a function of the specific combinations of adhesion molecules and chemokine receptors that they express. For example, naïve T lymphocytes use L-selectin (CD62L), the $\alpha \mathrm{L} \beta 2$-integrin (CD11a/CD18; LFA-1), and CCR7 to enter peripheral lymph nodes at high endothelial venules (130-132), while gut homing memory lymphocytes express the $\alpha 4 \beta 7$-integrin and CCR9 $(133,134)$, and memory lymphocytes targeted to the skin express the cutaneous lymphocyte antigen (CLA) and CCR4 (135). Cells capable of migrating to sites of inflammation display varying levels of CCR1, CCR2, CCR5, CXCR3, or other chemokine receptors on their surface $(130,136,137)$.

\section{Human NKT Cells}

Generally, human NKT cells express homing receptors for extralymphoid tissues (Table 1), with only $10-20 \%$ of circulating NKT cells expressing the lymph node homing receptor CCR7 $(87,89)$. Few blood NKT cells express the chemokine receptors CCR3, CCR9, CXCR1, CXCR2, CXCR5, or $\mathrm{CX}_{3} \mathrm{CR} 1(87,89)$. In contrast, a majority $(>60 \%)$ of NKT cells express CCR2, CCR5, CXCR3, and CXCR4, with differential expression of CCR1, CCR4, CCR6, and CXCR6 depending on the specific NKT cell subset or their tissue distribution $(87,88,138)$. Multiple studies examining chemokine receptor expression on human NKT cells have observed greater frequencies of $\mathrm{DN}$ and $\mathrm{CD} 8^{+} \mathrm{NKT}$ cells expressing CCR1, CCR2, CCR5, CCR6, CXCR6, and the integrin CD49a, while CCR 4 was expressed by a greater proportion of $\mathrm{CD} 4^{+} \mathrm{NKT}$ cells $(4,87,89,116,138)$. The frequency of circulating NKT cells that express CCR8, a skin homing receptor expressed on the majority of human T cells in healthy skin (139), ranges from 11 to $55 \%$ (140). Adhesion molecules such as CLA, CD62L, and $\alpha 4 \beta 7$ integrin are present on blood NKT cells to varying levels, with few CLA $^{+}$NKT cells (6-19\%), or CD62L ${ }^{+}$NKT cells (11-24\%), and a larger proportion expressing $\alpha 4 \beta 7$ (30-75\%) $(4,87)$. However, the co-expression of specific adhesion molecules and chemokine receptors on NKT cells is required for homing into certain tissues. The frequency of NKT cells expressing both CD62L and CCR7 is much lower than the fraction of cells expressing either receptor alone (87). This is likely to explain the low frequency of NKT cells in peripheral lymph nodes. The identification of distinct NKT cell subsets that exhibit differential cytokine production and unique patterns of homing receptors suggests that different NKT cell subsets can be targeted to different tissues or sites of inflammation. 


\section{Mouse NKT Cells}

Mouse NKT cells display significant differences in their chemokine receptor profiles and responsiveness to chemotactic ligands compared to human blood NKT cells. A majority of splenic mouse NKT cells express the receptors CCR9, CXCR3, CXCR4, and CXCR6 $(88,98)$, and TCR $\beta^{+} \mathrm{NK} 1.1^{+}$cells in $\mathrm{V} \alpha 14$ transgenic mice have elevated surface expression of CCR2, CCR5, and CCR9 (141). In contrast to human blood NKT cells, mouse blood, liver, spleen, and bone marrow NKT cells lack chemotactic responsiveness to ligands for CCR1, CCR2, CCR5, and CCR6 (88). Mouse NKT cells exhibited robust migration to the CXCR3 ligand monokine induced by gamma interferon (MIG; CXCL9) and the CXCR4 ligand stromal cell-derived factor 1 (SDF-1; CXCL12), while the CXCR6 ligand, CXCL16, only induced modest migration of NKT cells despite a large proportion of these cells expressing CXCR6 (Table 2) (88). This suggests that NKT cell responsiveness to CXCL16 and other chemokines is regulated. Consistent with this, responsiveness of $\mathrm{CD}^{+} \mathrm{T}$ cells to CXCL16 is dependent on activation (86), and increased chemotactic responsiveness to CXCL16 was observed in thymic NKT cells (91). Other tissue-specific differences among NKT cell subsets in terms of their chemokine receptor expression patterns or their chemotactic activity include the findings that a subset of NKT cells in the spleen, bone marrow, and blood, but not the liver, were responsive to the CCR7 ligand secondary lymphoid-tissue chemokine (SLC; CCL21), while a subset of CXCR5 ${ }^{+}$NKT cells were only present in the spleen and migrated in response to the CXCR5 ligand B cell-attracting chemokine 1 (BCA-1; CXCL13) (88). Ligands for CCR4 could mobilize lung NKT cells into the airways (108), but did not elicit chemotaxis of NKT cells derived from the spleen, liver, bone marrow, or blood (88), suggesting differences in CCR4 expression or regulation. Similarly, NKT cells in skin and peripheral lymph nodes express CCR6 and migrate in response to the ligand macrophage inflammatory protein $3 \alpha$ (MIP-3 $\alpha$; CCL20) (54), while spleen, liver, bone marrow, and blood NKT cells do not (88). As CCR6 expression on peripheral lymph node NKT cells correlates with a NKT-17 transcription profile, it will be interesting to correlate NKT cell localization and homing receptor expression in other tissues with the transcription factor expression patterns that have recently been used to classify NKT cell subsets.

Differential chemokine receptor expression on distinct NKT cell subsets suggests the potential to regulate homing to different tissue sites. However, the lack of functional chemotactic responses to many chemokine ligands suggests that chemokine receptor signaling is altered or regulated. Rather than contributing to tissue localization, some chemokines may play important roles in regulating NKT cell survival or effector functions. There is currently little known about the chemokine receptor profiles on activated NKT cells in comparison to resting NKT cells. In vitro activation of human NKT cells with $\alpha$-GalCer upregulated CCR6 protein expression on DN NKT cells relative to CD4 ${ }^{+}$NKT cells, while the $\mathrm{CD}^{+}$NKT cell subset displayed increased mRNA for $\mathrm{CX}_{3} \mathrm{CR} 1$ (142). Whether these changes mediate alterations in NKT cell localization and/or activity remain to be seen.

\section{NKT Cell Homing and Maturation}

During the developmental progression of thymocytes from immature $\mathrm{DN}$ precursors through the $\mathrm{CD} 4^{+} \mathrm{CD} 8^{+}$double positive (DP) stage to mature conventional single positive cells, a subset of chemokine receptors regulate cellular trafficking and positioning through the cortex (CXCR4), subcapsular zone (CCR9), and medulla (CCR4, CCR7) (143-146). It is unclear whether positioning is similar during NKT cell development, as these cells are selected via DP thymocytes rather than thymic stromal cells (68, 147). However, while CCR4 is not expressed on thymic NKT cells, CCR7 controls NKT cell development by enabling access to IL-15

TABLE 2 | Chemokine receptor expression and ligand responses on mouse NKT cells.

\begin{tabular}{|c|c|c|c|c|c|c|c|}
\hline \multirow[t]{2}{*}{ Receptor } & \multirow[t]{2}{*}{ Expression (\%) ${ }^{a}$} & \multicolumn{5}{|c|}{ Chemotactic response $^{b}$} & \multirow[t]{2}{*}{ Reference } \\
\hline & & Spleen & Liver & Bone Marrow & Blood & Other & \\
\hline CCR1 & n.d. & - & - & - & - & & (88) \\
\hline CCR2 & 23 & - & - & - & - & & $(88,141)$ \\
\hline CCR3 & n.d. & - & - & - & - & & (88) \\
\hline CCR4 & n.d. & - & - & - & - & Lung: ++ & $(88,108)$ \\
\hline CCR5 & $20-60$ & - & - & - & - & & $(88,93,141)$ \\
\hline CCR6 & PLN: 70-80 & - & - & - & - & PLN: ++ & $(54,88)$ \\
\hline CCR7 & Thymus: 15-60 & + & - & + & + & & (88) \\
\hline CCR8 & n.d. & - & & & & & (88) \\
\hline CCR9 & $18-80$ & - & & & & & $(88,98,141)$ \\
\hline CCR10 & n.d. & - & & & & & (88) \\
\hline CXCR2 & n.d. & - & - & - & - & & (88) \\
\hline CXCR3 & 80-96 & ++ & ++ & ++ & ++ & & (88) \\
\hline CXCR4 & $55-58$ & + & + & ++ & ++ & & (88) \\
\hline CXCR5 & Spleen: 35-38 & + & - & - & - & & (88) \\
\hline CXCR6 & $92-94$ & + & n.d. & n.d. & n.d. & Thymus: + & $(88,91)$ \\
\hline $\mathrm{CX}_{3} \mathrm{CR} 1$ & n.d. & - & - & - & - & & (88) \\
\hline XCR1 & n.d. & - & - & - & - & & (88) \\
\hline
\end{tabular}

${ }^{a}$ Range in reported frequency of receptor positive NKT cells.

${ }^{b}$ Net chemotactic migration: - (did not respond), $+(<25 \%)$, and $++(>25 \%)$.

n.d., not determined; PLN, peripheral lymph nodes. 
trans-presentation in the thymic medulla $(148,149)$. NKT cells upregulate the chemokine receptor CXCR6 during/after positive selection (91), which could also facilitate positioning within the medulla where the ligand CXCL16 is expressed (86).

Interestingly, the NKT cell pool in the thymus contains both "immature" NK1.1 ${ }^{-}$and mature NK1.1 ${ }^{+}$subsets (150). The expression of T-bet during maturation of NK1.1 ${ }^{-}$NKT cells induces the expression of CCR5 and CXCR3 (74). The interaction of CXCR3 with interferon- $\gamma$-induced protein 10 (IP-10; CXCL10) expressed by medullary thymic epithelial cells retains mature NK1.1 $1^{+} \mathrm{NKT}$ cells in the thymus as a long-lived resident population (151) (Figure 1). However, it remains unclear what role these retained mature NKT cells might play within the thymus as they appear to be absent in humans (112), and conventional $\mathrm{T}$ cell development is unaffected in NKT-cell deficient $\left(\mathrm{CD} \mathrm{d}^{-/-}\right)$ mice (152).

We have shown that NKT cells begin expressing high levels of CXCR6 in the thymus during the transition from $\mathrm{CD} 4^{+} \mathrm{CD} 8^{+}$ NKT cells to $\mathrm{CD}^{+}$and DN NKT cells following positive selection (91). CXCR6-deficiency does not affect thymic NKT cell development, but $\mathrm{CXCR}^{-/-}$mice exhibited a defect in the accumulation of mature CD1d-restricted NK1.1 ${ }^{+}$NKT cells in the periphery. Similarly, treatment of mice with a blocking antibody against CXCL16 did not inhibit accumulation of NK1.1 ${ }^{-}$recent thymic emigrants in the liver, but led to a defect in the accumulation of mature NK1.1 ${ }^{+}$NKT cells (91). These data point to a potential role for CXCR6 and CXCL16 in mediating maturation of $\mathrm{NK} 1.1^{-}$recent emigrant NKT cells, and retention and/or survival of mature NKT cells in the liver. A role for CXCR6 in retention is supported by the redistribution of NKT cells to the bone marrow in CXCR6 ${ }^{-1-}$ mice (91), while others have also implicated CXCR6 in NKT cell survival $(79,90)$.

CXCR6 $^{-1-}$ mice also exhibited impaired cytokine production by liver and spleen NKT cells following activation with $\alpha$-GalCer

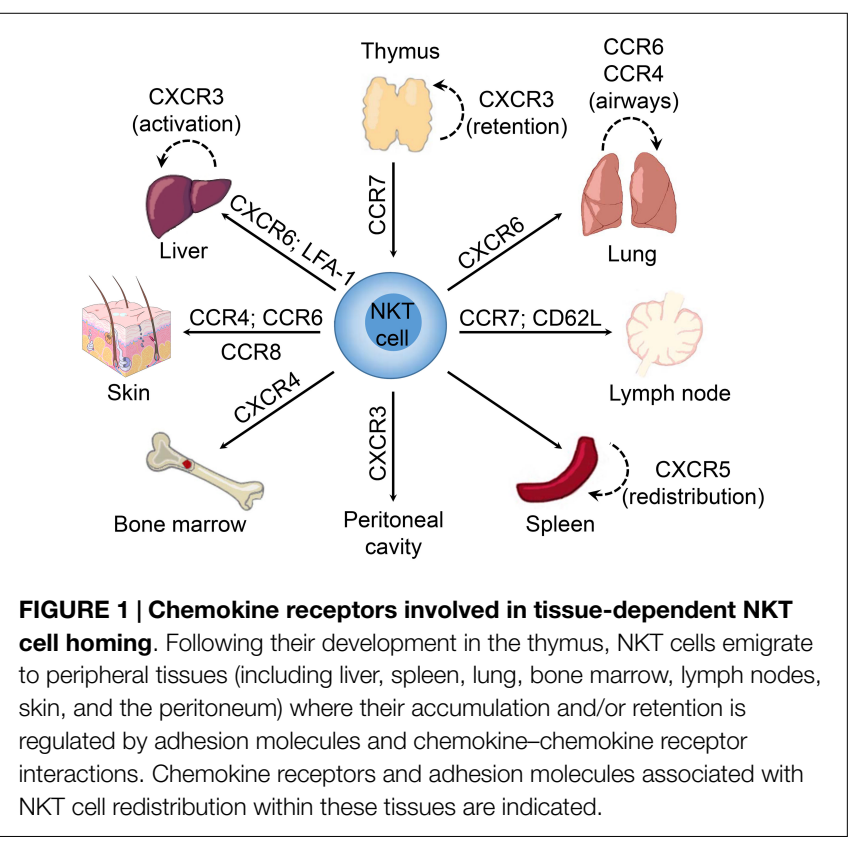

$(2,91)$. It is likely that CXCR6 delivers co-stimulatory signals to NKT cells as CXCL16 is expressed as a transmembrane protein on antigen-presenting cells $(86,153)$, and DCs from CXCL16 ${ }^{-1-}$ mice are impaired in their ability to stimulate IFN- $\gamma$ production from wild-type NKT cells (92). A reduction in IL-4 production by $\mathrm{CXCR}^{-l-} \mathrm{NKT}$ cells results from decreases in preformed IL-4 mRNA transcripts (91). Therefore, CXCR6 is critical for normal NKT cell development and function in addition to NKT cell homing and homeostasis. In addition to NKT cells, CXCR6 plays a role in regulating cytokine polarization in conventional $\mathrm{T}$ cell subsets. CXCR6 expression defines polarized subsets of Th1 and Th17 effector $\mathrm{T}$ cells in vivo $(154,155)$, and $\mathrm{T}$ cells from $\mathrm{CXCR}^{-1-}$ mice exhibit impaired IFN- $\gamma$ and IL-17 production in response to antigen restimulation in vitro (156).

Reporter mice in which the $C x c r 6$ coding region was replaced with green fluorescent protein $\left(C x c r 6^{\mathrm{gfp} /+}\right)$ have been used to show that liver NKT cells are localized within the vasculature, crawling along the luminal surface of liver sinusoids. Interestingly, although CXCR6-deficiency resulted in a significant reduction in NKT cell accumulation within the liver, it did not alter the crawling behavior of hepatic NKT cells (90), suggesting that other signals contribute to this behavior. The $\alpha \mathrm{L} \beta 2$-integrin (LFA-1) also appears to be important for the accumulation or retention of NKT cells within the liver, as mice deficient in LFA-1 have significantly reduced numbers of liver NKT cells $(157,158)$. Moreover, blockade of LFA-1 and intercellular adhesion molecule 1 (ICAM1) interactions resulted in a marked reduction in hepatic NKT cell numbers with a concomitant increase in NKT cell frequency within the peripheral blood (110).

Similar to the liver, NKT cells accumulate in the lung via CXCR6 (91), and reside as an intravascular population (108, 110). This strategic positioning may facilitate sensing of airborne antigens or infection as airway exposure to glycolipids or microbial cell wall components induced accumulation of NKT cells in the lung interstitium and bronchoalveolar space (108). This rapid redistribution of NKT cells preceded local expansion of the intravascular cells and did not appear to involve recruitment of NKT cells from the periphery. Multiple chemokines were induced in the lung after exposure to airborne NKT cell ligands (108), including known NKT cell attractants such as thymus and activation regulated chemokine (TARC; CCL17), MIG/CXCL9, and BCA-1/CXCL13 $(88,89,159)$. It was suggested that CCR4 may be important in regulating NKT cell redistribution in the lung, since aerosolized delivery of exogenous TARC/CCL17 was sufficient to drive extravasation of NKT cells into the lung parenchyma (108). These findings are consistent with previous work demonstrating that CCR4 mediates localization of NKT cells to the airways following aerosolized antigen challenge or delivery of $\alpha$-GalCer to the lungs (160).

In contrast to circulating naive conventional $\mathrm{T}$ lymphocytes, few NKT cells in mouse or human blood express both CD62L and CCR7 $(87,88)$, which is consistent with the relative scarcity of NKT cells within the lymph nodes. However, a subset of "immature" NK1.1 ${ }^{-}$NKT cells exhibited chemotaxis in response to CCR7 ligands in vitro (88). This was initially interpreted as a role for CCR7 in mediating the exit of immature NKT cells from the thymus, since chemotactic responsiveness to CCR7 ligands was 
not detected within mature NK1.1 ${ }^{+}$NKT cell subsets. However, this is also consistent with observations that a small subset of IL-17-generating NK1.1- NKT cells accumulates preferentially within lymph nodes $(3,54)$. Within the lymph nodes, NKT cells are highly motile and are located mainly in the interfollicular region and in the medulla, but are absent in the paracortex where most naïve conventional $\mathrm{T}$ cells reside (161). In contrast to this in situ distribution under resting conditions, adoptively transferred NKT cells derived from the liver, spleen, or lymph nodes of TCR transgenic mice localized primarily to the lymph node paracortex (162). While the basis for these distinct distribution patterns was not investigated, it is possible that alterations in homing properties were induced by the manipulations involved in isolation, purification, and transfer of NKT cells.

Natural killer T cell populations resident in peripheral lymph nodes and skin exhibit an NK1.1 ${ }^{-} \mathrm{CD} 4^{-}$phenotype, associated with expression of the retinoic acid receptor-related orphan receptor $\gamma \tau(\operatorname{ROR} \gamma \tau)$ transcription factor, and generate IL-17 following activation $(3,54,163,164)$. Similar to Th17 cells, IL-17producing NKT cells within the peripheral lymph nodes and skin in mice express CCR6 and migrate in response to the ligand MIP$3 \alpha /$ CCL20 (54), which has been shown to be involved in the recruitment of pathogenic Th17 cells to inflammatory sites in models of autoimmunity $(165,166)$. While it is unclear whether NKT-17 cells in the skin are distinct from those in the peripheral lymph nodes, it is thought that these cells are recruited via CCR6 and retained at epithelial sites by interactions between the $\alpha$ E-integrin (CD103) and E-cadherin (54). An NK1.1 ${ }^{-}$NKT cell population that produces IL-17 was also identified within the lung and shown to contribute to airway neutrophilia upon activation (56). While it is suggested that the NKT-17 lineage develops in the thymus of mice $(55,164)$, human and murine NKT cells can be differentiated into IL-17-producing cells in the presence of proinflammatory cytokines, such as IL-1 $\beta$ and IL-23, along with transforming growth factor- $\beta$ (TGF- $\beta$ ) (167, 168). Furthermore, both $\mathrm{CCR}^{+}$and $\mathrm{CCR}^{-}{ }^{-}$NKT cells from human blood contained cells that could produce IL-17 (167). This suggests plasticity in NKT cell populations, with the ability to be reprogramed in response to factors in the local tissue environment.

A subset of NKT cells in the spleen, but not in other tissues, expresses CXCR5 and actively migrates in response to BCA1/CXCL13 (88), a chemokine that mediates homing to B cell zones in lymphoid tissues (169-172). Subsequent studies demonstrated that $\mathrm{NKT}_{\mathrm{FH}}$ cells $\left(\mathrm{CXCR} 5^{+} \mathrm{PD}-1^{\mathrm{hi}}\right)$ could provide cognate help to $\mathrm{B}$ cells, leading to the formation of antibody-producing plasma cells $(65,129,173,174)$. In contrast to the intravascular localization of NKT cells in the liver and lungs (90, 110), NKT cells in the spleen are widely distributed under basal conditions, dispersed throughout the red and white pulp (175), the periarteriolar lymphoid sheath (110), the marginal zone (176), and occasionally in close proximity to the vasculature (177). Exogenous glycolipid antigens or infection with Streptococcus pneumoniae induced rapid accumulation and immobilization of splenic NKT cells in close proximity to marginal zone DCs and macrophages $(175,176)$. Importantly, the number of splenic CD1d-tetramer ${ }^{+}$ NKT cells were not significantly altered, suggesting that the accumulation in these areas of the spleen is due to redistribution and not enhanced recruitment of NKT cells from the peripheral blood (175).

\section{Role of NKT Cells in Microbial Host Defense}

Many studies have implicated roles for NKT cells in the immune responses elicited by microbial pathogens $(6,178-$ $180)$. NKT cells respond to a range of infectious organisms through the recognition of microbial lipids presented via $\mathrm{CD} \mathrm{d}^{+}$antigen presenting cells (181-187). For example, $\alpha$ galactosyldiacylglycerol from Borrelia burgdorferi (the causative agent of Lyme disease) (185), lipophosphoglycan from Leishmania donovani (188), $\alpha$-glucosyldiacylglycerol from $S$. pneumoniae (189), $\alpha$-glucuronosylceramide and $\alpha$-galacturonosylceramide from Sphingomonas species (182-185), and a cholesteryl $\alpha$ glucoside from Helicobacter pylori (186) are all recognized by the invariant TCR of NKT cells within the context of CD1d.

However, NKT cell activation is not restricted to microbes that contain lipid antigens recognized directly by the V $\alpha 14-J \alpha 18$ TCR on $i$ NKT cells. Other microbial products stimulate antigen presenting cells via pattern recognition receptors (TLRs, NOD-like receptors, etc.), causing enhanced accumulation of weak self-lipid antigens and the production of NKT cell-stimulating cytokines (IL-12, IL-18, and type I IFNs) (46, 184, 190-193). Endogenous lipid ligands induce weak signaling through the NKT cell TCR that is not sufficient for full NKT cell activation, but primes NKT cells to produce IFN- $\gamma$ upon exposure to the cytokines IL-12 and IL-18 (194). Moreover, there is evidence that CD1d-presented antigens may not be required and IL-12, IL-18, or type I IFNs alone or in combination may be sufficient to drive NKT cell activation and IFN- $\gamma$ production $(193,195)$.

The mode of activation may have implications for NKT cell localization and effector functions. In vitro, NKT cells form stable conjugates with $\alpha$-GalCer-pulsed DCs and subsequently lose motility, whereas NKT cells incubated with DCs in the presence of exogenous IL-12 and IL-18, or LPS-treated DCs, exhibit unaltered migration patterns (194). Consistent with this, NKT cell activation through intravenous delivery of exogenous glycolipid caused CD1d-dependent NKT cell arrest within liver sinusoids $(90,196)$ and induced rapid accumulation of NKT cells in the marginal zone of the spleen $(175,176)$. In contrast, while IL-12 and IL18 treatment induced CD1d-independent arrest in liver sinusoids (196), these cytokines did not induce NKT cell redistribution to the marginal zone within the spleen (175). This suggests a role for CD1d engagement and cell-cell interactions in regulating the specific localization and redistribution of NKT cells, while cytokine stimulated NKT cells likely adhere to local integrin ligands in response to inside out signaling. There could also be differences in the chemotactic signals and localization gradients elicited by antigenic versus cytokine stimuli.

\section{NKT Cells in Bacterial Infections}

\section{Borrelia burgdorferi}

Lyme disease is caused by $B$. burgdorferi, a bacterial spirochete that generates the NKT cell-stimulating glycolipid, $\alpha$ galactosyldiacylglycerol (185). NKT cell-deficient mice 
$\left(\mathrm{CD} 1 \mathrm{~d}^{-/-}\right.$and $\left.\mathrm{J} \alpha 18^{-/-}\right)$exhibit increased bacterial burden when infected with B. burgdorferi $(197,198)$. Under homeostatic conditions, NKT cells actively crawl within hepatic sinusoids (90). However, in mice systemically infected with B. burgdorferi, the majority ( $\sim 80 \%)$ of sinusoidal NKT cells arrested and formed clusters in stable contact with B. burgdorferi-containing Kupffer cells (197). Interestingly, antibody blockade of either CXCR3 or CD1d inhibited NKT cell arrest and cluster formation (197). Kupffer cells release substantial amounts of MIG/CXCL9 early following infection with B. burgdorferi (197), suggesting that a chemotactic gradient facilitates recruitment and interaction of CXCR3 $^{+}$NKT cells with CD1d ${ }^{+}$Kupffer cells. This response reflected a redistribution of hepatic NKT cells as there was little recruitment of additional NKT cells to the liver.

Intriguingly, the most prominent phenotype in B. burgdorferiinfected NKT cell-deficient mice was a greater abundance of bacteria in the joints $(197,198)$. This suggests that NKT cells play a role in limiting the emigration of B. burgdorferi out of the vasculature in Lyme disease-associated arthritis. In contrast to the intravascular distribution and patrolling behavior of NKT cells in the liver, Lee et al. (199) found that NKT cells in the joint were distributed throughout the extravascular tissue with the majority remaining stationary and in close contact with the blood vessels. Following B. burgdorferi infection, the spirochetes were found to adhere to the inner wall of joint blood vessels and attempt to extravasate into the tissue. Extravascular NKT cells in the vicinity of the adherent pathogen increased their crawling activity, suggesting the release and recognition of pathogen- or host-derived chemotactic factors, possibly complement-derived anaphylatoxins (199). Moreover, NKT cells played a critical role in clearance of $B$. burgdorferi from the joint tissue via direct granzyme-dependent killing (199). In contrast to the CD1ddependent responses to $B$. burgdorferi in the liver, NKT cellmediated pathogen recognition and killing activity in the joint was not dependent on CD1d interactions. This study highlights the importance of NKT cell positioning with respect to their antimicrobial function and identifies a functionally unique subset of bactericidal NKT cells in the joint, since liver and spleen NKT cells were unable to directly recognize and kill B. burgdorferi. Interestingly, NKT cells were found to be present in the normal joint under homeostatic conditions (199), and infection with $B$. burgdorferi did not result in enhanced accumulation of NKT cells within the joints in mice (198).

Extravascular NKT cells have also been detected in knee joints of B. burgdorferi infected patients $(199,200)$. Although there are fewer NKT cells in human joints compared to mice, synovial fluid from patients with osteoarthritis, rheumatoid arthritis, and Lyme arthritis contained increased numbers of activated NKT cells (199, 200). It is unclear if this represents redistribution or expansion of local NKT cells or recruitment of NKT cells from other sites. While this appears to contrast with the lack of increased NKT cell accumulation in mice with Lyme borreliosis, it could result from differences in the time course of disease or differences in the precise compartment within the joint from which samples were collected. Lee et al. (199) demonstrated that NKT cells were not uniformly distributed throughout the joint but rather were found predominantly at the joint surface, outside of the joint capsule. The increased number of NKT cells detected in synovial fluid samples from arthritis patients could represent a redistribution of extravascular joint-resident NKT cells into the joint capsule, which may be promoted by the presence of $B$. burgdorferi within synovial fluid. Consistent with this, Katchar et al. (200) observed a significantly higher proportion of NKT cells in the synovial fluid of patients with antibiotic-responsive Lyme arthritis (B. burgdorferi present in joint fluids in all patient samples) compared to the nearly undetectable levels of NKT cells in those with antibiotic-refractory Lyme arthritis (10 of 15 patients lacked detectable B. burgdorferi in joint fluids). T cells and NK cells were detected at similar levels in the synovial fluid of both patient groups, further suggesting that NKT cells play a key role in host defense against B. burgdorferi, and their absence may contribute to excessive inflammation and immune dysregulation in the joints of antibiotic-refractory Lyme arthritis patients.

\section{Chlamydia}

Chlamydia species are obligate intracellular pathogens that can cause numerous disease states in humans, including lung infection (201), gastrointestinal infection (202), urogenital infection (203), and reactive arthritis (204). Using an animal model of C. trachomatis-induced arthritis, Bharhani et al. (205) demonstrated that NKT cells play a role in ameliorating joint inflammation. Mice deficient in NKT cells $\left(\mathrm{CD}^{-1-} \mathrm{d}^{-/}\right)$exhibited enhanced arthritis severity, while $\alpha$-GalCer treatment of C. trachomatisinfected wild-type mice increased the accumulation of NKT cells within synovial tissues, reduced bacterial load, suppressed expression of inflammatory chemokines [macrophage inflammatory protein-2 (MIP-2) and IP-10/CXCL10], and decreased infiltration of inflammatory cells into the inflamed joint. Moreover, while Bharhani et al. (205) could not detect NKT cells in synovial tissues of control mice, synovial NKT cell populations were detected in $C$. trachomatis-infected mice, suggesting active recruitment of NKT cells to inflamed joints in these mice. However, since others have identified NKT cells in the joints of control mice (199), it is unclear whether the increased proportion of synovial NKT cells following $\alpha$-GalCer treatment of $C$. trachomatis-infected mice was due to further recruitment of NKT cells, or resulted from local NKT cell expansion.

Natural killer $\mathrm{T}$ cells have been shown to respond rapidly to infection and regulate microbial immunity in response to $C$. muridarum infections in the lung and genital tract of mice (206, 207), where treatment with $\alpha$-GalCer enhances IFN- $\gamma$ production to increase host resistance (207). Jiang et al. (208) reported elevations in bacterial burden and inflammatory cell infiltrate in the genital tract of CXCR5 $5^{-1-}$ mice infected with C. muridarum. While CXCR5-deficiency did not alter NKT cell accumulation in the genital tract, CXCR5 ${ }^{-1-}$ mice exhibited increased NKT cell activation in vitro and in vivo in response to $C$. muridarum infection. Enhanced production of IFN- $\gamma$ by NKT cells from $\mathrm{CXCR}^{-1-}$ mice suggests a possible role for CXCR5 in regulating the activity of NKT cells. However, enhanced NKT cell activity in $\mathrm{CXCR}^{-1-}$ mice did not provide greater protection against C. muridarum genital tract infection in vivo (208), implicating important roles for other $\mathrm{CXCR} 5^{+}$immune cells in mediating protective responses. 


\section{Streptococci/Cryptococci}

CD1d-dependent activation of NKT cells in response to $\alpha$ glucosyldiacylglycerol has been demonstrated in mice infected with S. pneumoniae and group B Streptococcus (causative agents of neonatal infections in humans) (189). This supports earlier studies implicating a critical role for NKT cells in early host defense against $S$. pneumoniae infection via their production of IFN $-\gamma$ and recruitment of neutrophils to infected lungs $(25,209)$. Consistent with a TCR-dependent activation mode, NKT cell activation and cytokine production in response to $S$. pneumoniae was associated with increased NKT cell GFP expression in Nur77-GFP mice, a reporter strain that upregulates GFP in response to TCR-mediated stimuli, but not TCR-independent inflammatory stimuli (210, 211). The frequency of lung NKT cells increased following $S$. pneumoniae infection, and following intratracheal infection with the fungal pathogen Cryptococcus neoformans $(25,212)$. In both cases, the increased NKT cell frequency may be dependent upon CCR2 and monocyte chemotactic protein 1 (MCP-1)/CCL2 mediated recruitment since the frequency of NKT cells was significantly reduced in the lungs of infected CCL2 ${ }^{-1-}$ mice compared to wild-type mice $(25,212)$. However, further studies are required to elucidate the relative contributions of NKT cell expansion and mobilization from lung parenchyma versus the recruitment of circulating NKT cells from the blood.

Natural killer $\mathrm{T}$ cells were found to promote antibody isotype switch, affinity maturation, and long-term memory B cell responses against pneumococcal capsular polysaccharides following delivery of a liposome nanoparticle vaccine containing $S$. pneumoniae capsular polysaccharide and a NKT cell-stimulating lipid (213). Antibody responses elicited by the vaccine were dependent upon cognate CD1d-restricted interactions between NKT cells and $B$ cells, a process that might be predicted to require direct $\mathrm{B}$ cell help provided by $\mathrm{NKT}_{\mathrm{FH}}$ cells. However, very little induction of CXCR5 ${ }^{+} \mathrm{PD}-1^{\text {hi }} \mathrm{NKT}_{\mathrm{FH}}$ cells was observed in immunized mice, suggesting a mostly extrafollicular response. These findings suggest that the inclusion of NKT cell ligands in microbial antigen-presenting liposomal particles may represent a simple and effective alternative to the conjugate vaccines currently used to elicit strong cognate help to $\mathrm{B}$ cells to promote protective and long lasting antibody responses.

\section{Bacterial Sepsis}

Chemokine receptor-mediated regulation of lymphocyte activation and homing has also been described during sepsis. In a mouse model of sepsis caused by cecal ligation and puncture (CLP), Herzig et al. (214) observed a CXCR3-dependent increase in peritoneal $\mathrm{NK}$ cell and $\mathrm{T}$ cell accumulation, likely due to increased concentrations of the chemokines MIG/CXCL9 and IP10/CXCL10 in the peritoneal cavity. In contrast, CLP did not result in an increased accumulation of NKT cells within the peritoneal cavity, but did decrease CXCR3 expression on NKT cells in the liver. The authors suggested this could be due to NKT cells becoming activated during CLP, causing the internalization and down-regulation of CXCR3 (214). Interestingly, the peritoneal cavity of CXCR3 $3^{-1-}$ mice was nearly devoid of NKT cells prior to and following induction of CLP, while CXCR3-deficiency had no impact on the numbers of NKT cells in the spleen (214). This suggests CXCR3 is important for the accumulation of NKT cells within the peritoneum under normal physiological conditions.

The anaphylatoxins (C3a and C5a), generated during complement activation, are chemotactic molecules that may also influence NKT cell localization and activation. NKT cells express high levels of mRNA, but not protein, for $\mathrm{C} 5 \mathrm{a}$ receptor (C5aR) under homeostatic conditions (215). However, upon Escherichia coliinduced sepsis in mice, C5aR protein is rapidly expressed on splenic NKT cells (215). Interestingly, NKT cells from C5aR $\mathrm{a}^{-1-}$ mice infected with $E$. coli expressed lower levels of the activation marker CD69 and had reduced secretion of IFN- $\gamma$ and TNF, suggesting that C5aR signaling regulates the activation of NKT cells in this model (215). Cognate C5a/C5aR interactions on NKT cells were also identified as a critical factor for NKT cell recruitment during sepsis based on the observations that $\mathrm{C}_{5} \mathrm{aR}^{-1-}$ mice had markedly reduced numbers of NKT cells in the spleen and peritoneal cavity following infection (215). Furthermore, E. coli infection induced greater accumulation of $\mathrm{C}_{5} \mathrm{aR}^{+}$ versus $\mathrm{C}_{5} \mathrm{aR}^{-} \mathrm{NKT}$ cells in the spleen of mixed bone marrow chimeras (215). The absence of C5aR and NKT cells were both associated with increased survival following infection, suggesting NKT cells contribute to the overwhelming inflammation in sepsis.

\section{Mycobacterium}

Activation of NKT cells via $\alpha$-GalCer has been shown to contribute to protection against $M$. tuberculosis in mice (216). Moreover, adoptive transfer of NKT cells decreased mycobacterial burden in the lung and spleen, and NKT cells were able to inhibit intracellular replication of M. tuberculosis within infected macrophages in vitro (217). CXCR6 on lung $\mathrm{T}$ cells has been proposed as a marker for protective immunity to $M$. tuberculosis after intranasal immunization in mice, with CXCR6 and CXCL16 playing a critical role in mediating the localization of $\mathrm{T}$ cells within the airways (218). It is possible that the CXCR6-CXCL16 axis is also important for NKT cell localization in these tissues as well, since lung NKT cells are reduced under baseline conditions in CXCR6 $^{-l-}$ mice (91).

Phosphatidylinositol-mannosides (PIMs) are phospholipid antigens located in the membranes of mycobacteria, some of which activate human and murine NKT cells via CD1d (181). Despite its inability to trigger expansion of NKT cells (181), $\mathrm{PIM}_{2}$ causes recruitment of NKT cells to the skin upon subcutaneous injection (219). Although this recruitment is TCR-independent, the mechanism is unclear. Intratracheal infection of mice with $M$. bovis bacillus Calmette-Guérin (BCG) induced NKT cell mobilization into the airways, which was profoundly impaired in $\mathrm{CCR}^{-1-}$ mice (220). In this study, lung parenchymal NKT cells in M. bovis BCG-infected wild-type mice were found to have high expression of CCR6, likely imbuing them with responsiveness to the high levels of MIP-3 $\alpha /$ CCL20 induced in the lungs by $M$. bovis BCG infection (220). The number of NKT cells in the lung parenchyma did not differ between wild-type and CCR $6^{-1-}$ mice, suggesting that the $>90 \%$ reduction in mobilization of NKT cells to the luminal airways in $M$. bovis BCG-infected $\mathrm{CCR}^{-1-}$ mice was due to a requirement for CCR6 in the airway infiltration but not lung localization of NKT cells (220). 


\section{NKT Cells in Viral Infections}

\section{Hepatitis Viruses}

In patients with chronic hepatitis B virus (HBV) infections, the frequency of circulating $\mathrm{CD}^{-}$NKT cells is lower than that in asymptomatic carriers or healthy controls, but infection did not impair the ability of peripheral NKT cells to produce IFN- $\gamma$ or IL4 in response to activation with either $\alpha$-GalCer or the mitogen phorbol 12-myristate 13-acetate (PMA) (221). Interestingly, the frequency of NKT cells increased significantly following antiviral therapy (221). However, it is unclear whether this reflects changes in proliferation, survival, or homing of NKT cells.

Although there has not been an exhaustive examination of chemokine receptors on NKT cells in patients infected with HBV, the frequency of NKT cells expressing CCR5 and CCR6 was comparable between chronic HBV patients and healthy controls (221). The migratory responses of NKT cells from chronic HBV patients to CCR5 and CCR6 ligands were either very modest (RANTES/CCL5) or not detectable (MIP-3 $\alpha /$ CCL20) compared to medium alone (221). However, the responses in this study were not compared to chemotactic responses of NKT cells from healthy controls.

A wide spectrum of clinical disease can occur following $\mathrm{HBV}$ infection, ranging from an asymptomatic carrier state, to self-limiting acute disease, chronic hepatitis, cirrhosis, liver failure, and hepatocellular carcinoma (222). A study in India reported a significantly increased frequency of circulating NKT

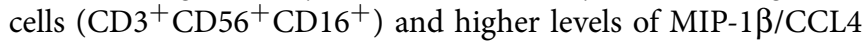
among patients with acute $\mathrm{HBV}$ infection, but not $\mathrm{HBV}$-induced liver failure, compared to healthy controls (223). However, a separate study reported a decline in circulating NKT cell $\left(\mathrm{CD}^{+}{ }^{+} \mathrm{CD}_{56}{ }^{+}\right)$frequencies in acute HBV patients in the first few weeks following hospital admission, which the authors suggested could be due to trafficking of NKT cells to the liver where they play a role in local HBV immunity (224). These studies need to be interpreted cautiously as $\mathrm{CD}^{+}{ }^{+} \mathrm{CD} 56^{+} / \mathrm{CD} 16^{+}$populations exhibit only partial overlap with the $i \mathrm{NKT}$ cell population.

Interestingly, Inoue et al. (225) reported higher surface expression (mean fluorescence intensity) of CXCR3 on circulating NKT cells isolated from patients with chronic hepatitis $\mathrm{C}$ virus (HCV) infection, while expression of CCR4, CCR7, or CD62L did not differ compared to healthy donors. The enhanced expression of CXCR3 may facilitate the trafficking of NKT cells to or within the liver due to the increased hepatic levels of MIG/CXCL9 and IP-10/CXCL10 during HCV infection (226, 227). Whether increased numbers of hepatic NKT cells during chronic HCV infection would be beneficial is unclear since NKT cells from $\mathrm{HCV}^{+}$patients produce more IL-13 and other Th2 cytokines (225), which could contribute to liver fibrosis during chronic viral hepatitis (228).

\section{Dengue Virus}

A recent study examining the role of NKT cells in the pathogenesis of dengue virus infection in humans found that peripheral NKT cell numbers were not altered over the course of dengue virus infection (229). However, NKT cells displayed an activated phenotype that correlated with increased disease severity (229).
Similarly, NKT cells exhibit an activated phenotype and appear to play a detrimental role during dengue infection in mice (230). NKT cell-deficient mice (J $\alpha 18^{-/-}$) exhibited resistance to lethal infection, which was associated with decreased systemic and local inflammatory responses, reduced production of inflammatory cytokines (IL-6, IFN- $\gamma$, and IL-12p40), and reduced levels of CXCL1, a chemokine known to rapidly mobilize and activate neutrophils (230). In wild-type mice, mast cells responding to dengue virus infection upregulated chemokine expression (RANTES/CCL5, SDF-1/CXCL12, and fractalkine/CX ${ }_{3}$ CL1), and mediated recruitment of $\mathrm{NKT}$ cells $\left(\mathrm{CD}^{+}{ }^{+} \mathrm{NK} 1.1^{+}\right)$into the skin at sites of dengue virus infection (231). Taken together, these data suggest NKT cells play a critical role in the pathogenesis of dengue disease.

\section{Influenza Virus}

Influenza virus is a respiratory pathogen that can be the cause of serious airway disease, particularly among children and the elderly. The number of circulating NKT cells were reduced in patients with severe cases of pandemic H1N1 influenza infection (232), but it is unclear whether this impacted disease progression. In rodent models, NKT cells play protective roles in influenza infection through multiple mechanisms. They have been reported to suppress excessive monocytic infiltrate (233), influence the generation of virus-specific $\mathrm{CD}^{+} \mathrm{T}$ cell responses (234), enhance the cytolytic activities of NK cells and virus-specific CD8 ${ }^{+} \mathrm{T}$ cells (via IFN- $\gamma$ production) (235), and selectively lyse virally infected cells through a CD1d-dependent mechanism (233). Interestingly, NKT cells were also found to reduce the expansion and immunosuppressive activity of influenza-induced myeloid-derived suppressor cells (236), an immune modulatory activity of NKT cells that has also been shown in cancer models (237).

Much of the research on NKT cells in influenza infection focuses on the potential for NKT cell-stimulating glycolipid agonists such as $\alpha$-GalCer to act as vaccine adjuvants. Several studies have shown that intranasal immunization of inactivated influenza or a live attenuated influenza vaccine, together with $\alpha$-GalCer or its derivatives, induced high levels of influenza-specific systemic IgG and mucosal IgA, influenza-specific $\mathrm{CD}^{+} \mathrm{T}$ cell memory responses, and complete protection against influenza viral challenge in mice (238-242). Intranasal administration of $\alpha$-GalCer was shown to increase the NKT cell populations in nasopharyngeal-associated lymphoid tissue (NALT) and regional cervical lymph nodes, but not the spleen, indicating that nasal administration of $\alpha$-GalCer influences the local NKT cell population size without altering the systemic NKT cell population (242). Interestingly, expression of CXCL16 was upregulated in NALT and cervical lymph nodes following vaccination. NKT cell accumulation within these tissues and influenza-specific mucosal IgA levels were reduced in CXCL16 ${ }^{-1-}$ mice (242). Therefore CXCR6-CXCL16 interactions contribute to the increased population of NKT cells following nasal influenza vaccination either by regulating homing or expansion of these cells. It would be interesting to determine whether influenza vaccination in conjunction with intranasal $\alpha$-GalCer administration also increases the NKT cell population in the lung and/or airways, and if so, whether this increase is also impaired in CXCL16 $6^{-/-}$mice. 


\section{Human Immunodeficiency Virus}

Natural killer T cells are highly susceptible to infection with HIV1 due to the expression of multiple co-receptors for viral fusion and entry, including CD4 and the chemokine receptors CCR5, CXCR4, and CXCR6 (138, 243-248). Indeed, NKT cell frequency is reduced in patients with HIV-1 infection, with a preferential depletion of the $\mathrm{CD} 4^{+}$NKT cell subset prior to depletion of conventional $\mathrm{CD}^{+} \mathrm{T}$ cells $(243,248-250)$. Interestingly, the frequency of CCR $5^{+}$NKT cells was higher in $\mathrm{HIV}-1^{+}$patients, while $\mathrm{CXCR}^{+}, \mathrm{CCR}^{+}$, and $\mathrm{CCR} 7^{+} \mathrm{NKT}$ cell frequencies were reduced compared to healthy individuals $(251,252)$. Circulating NKT cell populations have been shown to recover early following effective antiretroviral therapy, but treatment failed to restore CXCR6 or CCR2 expression on NKT cells (252). Some have speculated that the rapid recovery of NKT cells after treatment is partly due to NKT cell redistribution from tissue sites to the circulation, a phenomenon that has been observed for conventional $\mathrm{T}$ cells in HIV- $1^{+}$patients following therapy $(253,254)$.

In addition to influencing circulating NKT cell numbers, HIV1 infection also impairs the proliferative and cytokine-producing capacities of persisting NKT cells in chronic $\mathrm{HIV}_{-}{ }^{+}$patients $(255,256)$. However, the role of NKT cells in HIV-1 infection remains unclear since some studies report no correlation between NKT cell numbers and HIV disease progression (249), while others have suggested an association between higher levels of $\mathrm{CD} 4^{+}$ NKT cells and lower plasma viremia (243). NKT cell activation with $\alpha$-GalCer has shown promise as a vaccine adjuvant in animal models when combined with delivery of HIV-1 DNA and peptide antigens $(257,258)$, suggesting that NKT cells have the potential to play important roles during HIV-1 infection.

Natural killer $\mathrm{T}$ cells from $\mathrm{HIV}-1^{+}$patients expand in vitro following treatment with IL-15 and IL-12 (251), and a combination of antiretroviral therapy with exogenous IL-2 promotes a greater increase in circulating NKT cell numbers than standard therapy alone (259). Therefore, the reduced peripheral NKT cell population in HIV-1-infected individuals is likely due to a combination of factors, which include direct HIV-1 infection of NKT cells and subsequent cell death, tissue redistribution of NKT cells, and impaired generation and/or responsiveness to cytokines that promote NKT cell survival. A better understanding of the mechanisms contributing to NKT cell depletion in $\mathrm{HIV}_{-1}{ }^{+}$patients could lead to the development of new therapeutic strategies to restore NKT cell numbers and lead to better clinical outcomes following HIV-1 infection.

\section{Conclusion and Outstanding Questions}

Our understanding of the distinct phenotypic and functional subsets of NKT cells continues to improve, allowing for clearer interpretations of how NKT cells contribute to health and disease. Under homeostatic conditions, NKT cells can be found in many tissues throughout the body, and NKT cell accumulation within specific sites can be linked to the expression of specific chemokine receptors and adhesion molecules that mediate tissue homing, retention, and/or survival (e.g., liver accumulation via CXCR6 and LFA-1). Upon activation, local NKT cell populations can expand and use chemotactic signals to relocalize within a tissue.
However, in most cases, there is little or no evidence that NKT cells are recruited to sites of inflammation from the blood or other tissues. Despite their low numbers, NKT cells influence the magnitude and polarization of immune responses in a wide array of contexts ranging from antimicrobial and antitumor responses to autoimmunity. However, many questions remain regarding the roles of NKT cells in these conditions.

Patients with chronic microbial infection, autoimmune disorders, and malignancies often have alterations in the number and functional activity of NKT cells $(7,119,122,260,261)$. Some have speculated that reduced NKT cell numbers in the peripheral blood of these patients are linked to NKT cell trafficking to diseased tissue sites associated with these disorders (120, 224, 262-264). However, reduced NKT cell numbers or other NKT cell defects in many disease states may be associated with the standard therapies used to treat the disease rather than the disease itself. For example, reduced NKT cell frequencies were not observed in patients with myelodysplastic syndrome or multiple myeloma prior to treatment, but defects in peripheral NKT cells emerged following initiation of standard therapy $(265,266)$. In most diseases in which NKT cell numbers are affected, further investigation is required to track whether alterations in NKT cell numbers are due to altered trafficking or redistribution of NKT cells to various tissue sites. This will require that studies examine patients multiple times over the course of disease development and ideally include multiple tissues and treatment-naïve groups, rather than only examining patients on a single occasion after disease onset as most studies have done to date. Doing so will allow clearer correlations to be made between altered NKT cell numbers/function (i.e., altered subset frequencies and cytokine production) and disease progression, and ultimately provide evidence as to whether NKT cell defects are a cause or consequence of the disease process.

Under homeostatic conditions, NKT cells appear to be tissueresident populations and exhibit very little exchange with NKT cells in the circulation, as evidenced by studies using parabiotic congenic mice. NKT cells in the blood in these pairs reach almost equal (50\%) chimerism, while those in the lung, liver, spleen, lymph nodes, bone marrow, and other tissues did not recirculate, with nearly all NKT cells in these tissues originating from the host $(59,108,110)$. In contrast, conventional CD4 ${ }^{+}$ and $\mathrm{CD}^{+} \mathrm{T}$ cells, $\mathrm{B}$ cells, and NK cells rapidly recirculate and equilibrated in these tissues (110). This poses interesting questions regarding NKT cell redistribution during microbial infection. Multiple studies described above have observed greater NKT cell accumulation in affected tissues in a variety of infections. However, in many studies, the authors have not distinguished between the possibilities of NKT cell recruitment into the tissue versus expansion and relocalization of tissue resident NKT cells. Regardless, their accumulation at sites of infection ensures NKT cells are exposed to potential activating stimuli, either directly through specific recognition of microbial lipid antigens or indirectly through self-glycolipid and cytokine stimulation. Intriguingly, NKT cells may not need to be present in an affected tissue site in order to respond and subsequently influence the immune response within the host. For example, liver NKT cells responding directly to noradrenergic neurotransmitters were shown to release anti-inflammatory cytokines that induced a state of immune 
suppression that rendered mice susceptible to bacterial infection following ischemic cerebral stroke (47). Similarly, NKT cells are activated in the liver during the induction of contact hypersensitivity reactions (267). Therefore, a lack of NKT cell accumulation within inflamed peripheral tissues during infection may not preclude effective (or deleterious) antimicrobial immune responses mediated by tissue-resident NKT cells at a distant site.

A number of NKT cell subsets have been described that exhibit distinct phenotypes and functions in terms of surface marker expression and cytokine profiles. For example, lymph node resident $\mathrm{CCR}^{+}{ }^{+} \mathrm{CD} 4^{-} \mathrm{NK} 1.1^{-} \mathrm{NKT}$ cells described earlier express the transcription factor ROR $\gamma \tau$ and produce IL-17 in response to inflammatory signals (54). Unique transcriptional programs have been identified for NKT-1, NKT-2, NKT-10, and NKT-17 subsets of NKT cells within the thymus (52-58). Recent data reveal that NKT cell lineage fate is regulated by lethal-7 (let-7) microRNAs (miRNAs), which target Zbtb16 mRNA (encoding PLZF) to posttranscriptionally regulate the expression of PLZF protein (268). The expression of let-7 miRNAs was dynamically regulated during NKT cell development, with IL-15 and other stimuli present in the thymic medulla contributing to upregulated let-7 miRNAs and reduced levels of PLZF protein during NKT cell differentiation.

\section{References}

1. Cohen NR, Garg S, Brenner MB. Antigen presentation by CD1 lipids, T cells, and NKT cells in microbial immunity. Adv Immunol (2009) 102:1-94. doi:10.1016/S0065-2776(09)01201-2

2. Cullen R, Germanov E, Shimaoka T, Johnston B. Enhanced tumor metastasis in response to blockade of the chemokine receptor CXCR6 is overcome by NKT cell activation. J Immunol (2009) 183:5807-15. doi:10.4049/jimmunol. 0803520

3. Coquet JM, Chakravarti S, Kyparissoudis K, McNab FW, Pitt LA, McKenzie BS, et al. Diverse cytokine production by NKT cell subsets and identification of an IL-17-producing CD4 ${ }^{-}$NK1.1 ${ }^{-}$NKT cell population. Proc Natl Acad Sci U S A (2008) 105:11287-92. doi:10.1073/pnas.0801631105

4. Gumperz JE, Miyake S, Yamamura T, Brenner MB. Functionally distinct subsets of CD1d-restricted natural killer T cells revealed by CD1d tetramer staining. J Exp Med (2002) 195:625-36. doi:10.1084/jem.20011786

5. Kinjo Y, Kitano N, Kronenberg M. The role of invariant natural killer T cells in microbial immunity. J Infect Chemother (2013) 19:560-70. doi:10.1007/ s10156-013-0638-1

6. Tupin E, Kinjo Y, Kronenberg M. The unique role of natural killer T cells in the response to microorganisms. Nat Rev Microbiol (2007) 5:405-17. doi:10. 1038/nrmicro1657

7. Simoni Y, Diana J, Ghazarian L, Beaudoin L, Lehuen A. Therapeutic manipulation of natural killer (NK) T cells in autoimmunity: are we close to reality? Clin Exp Immunol (2013) 171:8-19. doi:10.1111/j.1365-2249.2012.04625.x

8. Wu L, Van Kaer L. Natural killer T cells and autoimmune disease. Curr Mol Med (2009) 9:4-14. doi:10.2174/156652409787314534

9. Iwamura C, Nakayama T. Role of NKT cells in allergic asthma. Curr Opin Immunol (2010) 22:807-13. doi:10.1016/j.coi.2010.10.008

10. Meyer EH, DeKruyff RH, Umetsu DT. T cells and NKT cells in the pathogenesis of asthma. Annu Rev Med (2008) 59:281-92. doi:10.1146/annurev.med.59. 061506.154139

11. Robertson FC, Berzofsky JA, Terabe M. NKT cell networks in the regulation of tumor immunity. Front Immunol (2014) 5:543. doi:10.3389/fimmu.2014. 00543

12. Gapin L, Matsuda JL, Surh CD, Kronenberg M. NKT cells derive from doublepositive thymocytes that are positively selected by CD1d. Nat Immunol (2001) 2:971-8. doi:10.1038/ni710

13. Godfrey DI, Stankovic S, Baxter AG. Raising the NKT cell family. Nat Immunol (2010) 11:197-206. doi:10.1038/ni.1841
NKT cells with downregulated levels of PLZF differentiated into IFN- $\gamma$-producing NKT-1 cells. Conversely, reduced expression of let-7 miRNAs resulted in greater levels of PLZF protein and a thymic bias toward NKT-2 and NKT-17 differentiation. However, this bias was less evident in the peripheral tissues (liver, spleen, and lymph nodes) of mice with reduced let-7 miRNAs (268), suggesting the relative frequencies of NKT cell effector subsets are influenced by differential migration and expansion of certain NKT cell effector lineages within specific tissue microenvironments. Nevertheless, it will be important to determine whether different NKT cell subsets in vivo represent committed lineages of cells with distinct homing receptors or if these subsets exhibit plasticity and are able to adopt various functional roles depending upon soluble and cell-associated signals received within a given tissue microenvironment. Furthermore, a focused research effort is needed to investigate the relative roles of distinct NKT cell subsets during microbial infection.

\section{Acknowledgments}

This work is supported by a grant from the Canadian Institutes of Health Research.

14. Zhou D, Mattner J, Cantu C, Schrantz N, Yin N, Gao Y, et al. Lysosomal glycosphingolipid recognition by NKT cells. Science (2004) 306:1786-9. doi:10. 1126/science. 1103440

15. Fox LM, Cox DG, Lockridge JL, Wang X, Chen X, Scharf L, et al. Recognition of lyso-phospholipids by human natural killer T lymphocytes. PLoS Biol (2009) 7:e1000228. doi:10.1371/journal.pbio.1000228

16. Facciotti F, Ramanjaneyulu GS, Lepore M, Sansano S, Cavallari M, Kistowska $\mathrm{M}$, et al. Peroxisome-derived lipids are self antigens that stimulate invariant natural killer T cells in the thymus. Nat Immunol (2012) 13:474-80. doi:10. 1038/ni.2245

17. Brennan PJ, Tatituri RV, Brigl M, Kim EY, Tuli A, Sanderson JP, et al. Invariant natural killer $\mathrm{T}$ cells recognise lipid self antigen induced by microbial danger signals. Nat Immunol (2011) 12:1202-11. doi:10.1038/ni.2143

18. Kain L, Webb B, Anderson BL, Deng S, Holt M, Costanzo A, et al. The identification of the endogenous ligands of natural killer $\mathrm{T}$ cells reveals the presence of mammalian $\alpha$-linked glycosylceramides. Immunity (2014) 41:543-54. doi:10. 1016/j.immuni.2014.08.017

19. Christiansen D, Milland J, Mouhtouris E, Vaughan H, Pellicci DG, McConville MJ, et al. Humans lack iGb3 due to the absence of functional iGb3-synthase: implications for NKT cell development and transplantation. PLoS Biol (2008) 6:e172. doi:10.1371/journal.pbio.0060172

20. Brennan PJ, Tatituri RV, Heiss C, Watts GF, Hsu FF, Veerapen N, et al. Activation of iNKT cells by a distinct constituent of the endogenous glucosylceramide fraction. Proc Natl Acad Sci U S A (2014) 111:13433-8. doi:10. 1073/pnas.1415357111

21. Lantz O, Bendelac A. An invariant T cell receptor $\alpha$ chain is used by a unique subset of major histocompatibility complex class I-specific CD4 ${ }^{+}$ and CD4 ${ }^{-} 8^{-}$T cells in mice and humans. J Exp Med (1994) 180:1097-106. doi:10.1084/jem.180.3.1097

22. Porcelli S, Yockey CE, Brenner MB, Balk SP. Analysis of T cell antigen receptor (TCR) expression by human peripheral blood CD4 ${ }^{-} 8^{-} \alpha / \beta$ T cells demonstrates preferential use of several V $\beta$ genes and an invariant TCR $\alpha$ chain. J Exp Med (1993) 178:1-16. doi:10.1084/jem.178.1.1

23. Benlagha $\mathrm{K}$, Weiss $\mathrm{A}$, Beavis $\mathrm{A}$, Teyton L, Bendelac A. In vivo identification of glycolipid antigen-specific T cells using fluorescent CD1d tetramers. J Exp Med (2000) 191:1895-903. doi:10.1084/jem.191.11.1895

24. Matsuda JL, Naidenko O, Gapin L, Nakayama T, Taniguchi M, Wang $\mathrm{CR}$, et al. Tracking the response of natural killer $\mathrm{T}$ cells to a glycolipid antigen using CD1d tetramers. J Exp Med (2000) 192:741-54. doi:10.1084/jem. 192.5.741 
25. Kawakami K, Yamamoto N, Kinjo Y, Miyagi K, Nakasone C, Uezu K, et al. Critical role of ${\mathrm{V} \alpha 14^{+}}^{+}$natural killer $\mathrm{T}$ cells in the innate phase of host protection against Streptococcus pneumoniae infection. Eur J Immunol (2003) 33:3322-30. doi:10.1002/eji.200324254

26. Ho LP, Denney L, Luhn K, Teoh D, Clelland C, McMichael AJ. Activation of invariant NKT cells enhances the innate immune response and improves the disease course in influenza A virus infection. Eur J Immunol (2008) 38:1913-22. doi:10.1002/eji.200738017

27. Bilenki L, Yang J, Fan Y, Wang S, Yang X. Natural killer T cells contribute to airway eosinophilic inflammation induced by ragweed through enhanced IL4 and eotaxin production. Eur J Immunol (2004) 34:345-54. doi:10.1002/eji. 200324303

28. Shimizu K, Goto A, Fukui M, Taniguchi M, Fujii S. Tumor cells loaded with $\alpha$-galactosylceramide induce innate NKT and NK cell-dependent resistance to tumor implantation in mice. J Immunol (2007) 178:2853-61. doi:10.4049/ jimmunol.178.5.2853

29. Arrenberg P, Halder R, Dai Y, Maricic I, Kumar V. Oligoclonality and innatelike features in the TCR repertoire of type II NKT cells reactive to a $\beta$-linked self-glycolipid. Proc Natl Acad Sci U S A (2010) 107:10984-9. doi:10.1073/pnas. 1000576107

30. Park SH, Weiss A, Benlagha K, Kyin T, Teyton L, Bendelac A. The mouse CD1d-restricted repertoire is dominated by a few autoreactive $\mathrm{T}$ cell receptor families. J Exp Med (2001) 193:893-904. doi:10.1084/jem.193.8.893

31. Patel O, Pellicci DG, Gras S, Sandoval-Romero ML, Uldrich AP, Mallevaey $\mathrm{T}$, et al. Recognition of CD1d-sulfatide mediated by a type II natural killer T cell antigen receptor. Nat Immunol (2012) 13:857-63. doi:10.1038/ni. 2372

32. Terabe M, Swann J, Ambrosino E, Sinha P, Takaku S, Hayakawa Y, et al. A nonclassical non-V $\alpha 14 \mathrm{~J} \alpha 18 \mathrm{CD} 1 \mathrm{~d}-$ restricted (type II) NKT cell is sufficient for down-regulation of tumor immunosurveillance. J Exp Med (2005) 202:1627-33. doi:10.1084/jem.20051381

33. Ambrosino E, Terabe M, Halder RC, Peng J, Takaku S, Miyake S, et al. Crossregulation between type I and type II NKT cells in regulating tumor immunity: a new immunoregulatory axis. J Immunol (2007) 179:5126-36. doi:10.4049/ jimmunol.179.8.5126

34. Renukaradhya GJ, Khan MA, Vieira M, Du W, Gervay-Hague J, Brutkiewicz RR. Type I NKT cells protect (and type II NKT cells suppress) the host's innate antitumor immune response to a B-cell lymphoma. Blood (2008) 111:5637-45. doi:10.1182/blood-2007-05-092866

35. Girardi E, Maricic I, Wang J, Mac TT, Iyer P, Kumar V, et al. Type II natural killer $\mathrm{T}$ cells use features of both innate-like and conventional $\mathrm{T}$ cells to recognize sulfatide self antigens. Nat Immunol (2012) 13:851-6. doi:10.1038/ ni.2371

36. Zhang G, Nie H, Yang J, Ding X, Huang Y, Yu H, et al. Sulfatide-activated type II NKT cells prevent allergic airway inflammation by inhibiting type I NKT cell function in a mouse model of asthma. Am J Physiol Lung Cell Mol Physiol (2011) 301:975-84. doi:10.1152/ajplung.00114.2011

37. Halder RC, Aguilera C, Maricic I, Kumar V. Type II NKT cell - mediated anergy induction in type I NKT cells prevents inflammatory liver disease. $J$ Clin Invest (2007) 117:2302-12. doi:10.1172/JCI31602.2302

38. Arrenberg P, Maricic I, Kumar V. Sulfatide-mediated activation of type II natural killer $\mathrm{T}$ cells prevents hepatic ischemic reperfusion injury in mice. Gastroenterology (2011) 140:646-55. doi:10.1053/j.gastro.2010.10.003

39. Jahng A, Maricic I, Aguilera C, Cardell S, Halder RC, Kumar V. Prevention of autoimmunity by targeting a distinct, noninvariant $\mathrm{CD} 1 \mathrm{~d}$-reactive $\mathrm{T}$ cell population reactive to sulfatide. J Exp Med (2004) 199:947-57. doi:10.1084/ jem.20031389

40. Kwiecinski J, Rhost S, Löfbom L, Blomqvist M, Månsson JE, Cardell SL, et al. Sulfatide attenuates experimental Staphylococcus aureus sepsis through a CD1d-dependent pathway. Infect Immun (2013) 81:1114-20. doi:10.1128/ IAI.01334-12

41. Fuss IJ, Heller F, Boirivant M, Leon F, Yoshida M, Fichtner-Feigl S, et al. Nonclassical CD1d-restricted NK T cells that produce IL-13 characterize an atypical Th2 response in ulcerative colitis. J Clin Invest (2004) 113:1490-7. doi:10.1172/JCI19836

42. Liao CM, Zimmer MI, Shanmuganad S, Yu HT, Cardell SL, Wang CR. Dysregulation of CD1d-restricted type II natural killer T cells leads to spontaneous development of colitis in mice. Gastroenterology (2012) 142:326-34. doi:10. 1053/j.gastro.2011.10.030
43. Exley MA, Tahir SM, Cheng O, Shaulov A, Joyce R, Avigan D, et al. A major fraction of human bone marrow lymphocytes are Th2-like CD1d-reactive $\mathrm{T}$ cells that can suppress mixed lymphocyte responses. J Immunol (2001) 167:5531-4. doi:10.4049/jimmunol.167.10.5531

44. Montoya CJ, Jie HB, Al-Harthi L, Mulder C, Patino PJ, Rugeles MT, et al. Activation of plasmacytoid dendritic cells with TLR9 agonists initiates invariant NKT cell-mediated cross-talk with myeloid dendritic cells. J Immunol (2006) 177:1028-39. doi:10.4049/jimmunol.177.2.1028

45. Coquet JM, Kyparissoudis K, Pellicci DG, Besra G, Berzins SP, Smyth MJ, et al. IL-21 is produced by NKT cells and modulates NKT cell activation and cytokine production. J Immunol (2007) 178:2827-34. doi:10.4049/jimmunol. 178.5.2827

46. Brigl M, Tatituri R, Watts GF, Bhowruth V, Leadbetter EA, Barton N, et al. Innate and cytokine-driven signals, rather than microbial antigens, dominate in natural killer T cell activation during microbial infection. J Exp Med (2011) 208:1163-77. doi:10.1084/jem.20102555

47. Wong $\mathrm{CH}$, Jenne $\mathrm{CN}$, Lee WY, Léger C, Kubes P. Functional innervation of hepatic iNKT cells is immunosuppressive following stroke. Science (2011) 334:101-5. doi:10.1126/science.1210301

48. Askenase PW, Itakura A, Leite-de-Moraes MC, Lisbonne M, Roongapinun S, Goldstein DR, et al. TLR-dependent IL-4 production by invariant $\mathrm{V} \alpha 14^{+} \mathrm{J} \alpha 18^{+}$NKT cells to initiate contact sensitivity in vivo. J Immunol (2005) 175:6390-401. doi:10.4049/jimmunol.175.10.6390

49. Grela F, Aumeunier A, Bardel E, Van LP, Bourgeois E, Vanoirbeek J, et al. The TLR7 agonist R848 alleviates allergic inflammation by targeting invariant NKT cells to produce IFN- $\gamma$. J Immunol (2011) 186:284-90. doi:10.4049/jimmunol. 1001348

50. Kim JH, Kim HS, Kim HY, Oh SJ, Chung DH. Direct engagement of TLR4 in invariant NKT cells regulates immune diseases by differential IL-4 and IFN- $\gamma$ production in mice. PLoS One (2012) 7:e45348. doi:10.1371/journal. pone. 0045348

51. Paget C, Ivanov S, Fontaine J, Renneson J, Blanc F, Pichavant M, et al. Interleukin-22 is produced by invariant natural killer $\mathrm{T}$ lymphocytes during influenza A virus infection: potential role in protection against lung epithelial damages. J Biol Chem (2012) 287:8816-29. doi:10.1074/jbc.M111.304758

52. Brennan PJ, Brigl M, Brenner MB. Invariant natural killer T cells: an innate activation scheme linked to diverse effector functions. Nat Rev Immunol (2013) 13:101-17. doi:10.1038/nri3369

53. Constantinides MG, Bendelac A. Transcriptional regulation of the NKT cell lineage. Curr Opin Immunol (2013) 25:161-7. doi:10.1016/j.coi.2013.01.003

54. Doisne JM, Becourt C, Amniai L, Duarte N, Le Luduec JB, Eberl G, et al. Skin and peripheral lymph node invariant NKT cells are mainly retinoic acid receptor-related orphan receptor $\gamma^{+}{ }^{+}$and respond preferentially under inflammatory conditions. J Immunol (2009) 183:2142-9. doi:10.4049/jimmunol. 0901059

55. Lee YJ, Holzapfel KL, Zhu J, Jameson SC, Hogquist KA. Steady-state production of IL- 4 modulates immunity in mouse strains and is determined by lineage diversity of iNKT cells. Nat Immunol (2013) 14:1146-54. doi:10.1038/ni.2731

56. Michel ML, Keller AC, Paget C, Fujio M, Trottein F, Savage PB, et al. Identification of an IL-17-producing NK1.1neg iNKT cell population involved in airway neutrophilia. J Exp Med (2007) 204:995-1001. doi:10.1084/jem. 20061551

57. Sag D, Krause P, Hedrick CC, Kronenberg M, Wingender G. IL-10-producing NKT10 cells are a distinct regulatory invariant NKT cell subset. J Clin Invest (2014) 124:3725-40. doi:10.1172/JCI72308

58. Watarai H, Sekine-Kondo E, Shigeura T, Motomura Y, Yasuda T, Satoh R, et al. Development and function of invariant natural killer $\mathrm{T}$ cells producing $\mathrm{TH} 2$ and TH17-cytokines. PLoS Biol (2012) 10:e1001255. doi:10.1371/journal.pbio. 1001255

59. Lynch L, Michelet X, Zhang S, Brennan PJ, Moseman A, Lester C, et al. Regulatory iNKT cells lack expression of the transcription factor PLZF and control the homeostasis of Treg cells and macrophages in adipose tissue. Nat Immunol (2015) 16:85-96. doi:10.1038/ni.3047

60. Carnaud C, Lee D, Donnars O, Park S, Beavis A, Koezuka Y, et al. Cutting edge: cross-talk between cells of the innate immune system: NKT cells rapidly activate NK cells. J Immunol (1999) 163:4647-50.

61. Fujii S, Shimizu K, Smith C, Bonifaz L, Steinman RM. Activation of natural killer T cells by $\alpha$-galactosylceramide rapidly induces the full maturation of dendritic cells in vivo and thereby acts as an adjuvant for combined CD4 
and CD8 T cell immunity to a coadministered protein. J Exp Med (2003) 198:267-79. doi:10.1084/jem.20030324

62. Münz C, Steinman RM, Fujii S. Dendritic cell maturation by innate lymphocytes: coordinated stimulation of innate and adaptive immunity. J Exp Med (2005) 202:203-7. doi:10.1084/jem.20050810

63. Dondji B, Deak E, Goldsmith-Pestana K, Perez-Jimenez E, Esteban M, Miyake $S$, et al. Intradermal NKT cell activation during DNA priming in heterologous prime-boost vaccination enhances $\mathrm{T}$ cell responses and protection against Leishmania. Eur J Immunol (2008) 38:706-19. doi:10.1002/eji.200737660

64. Godfrey DI, Kronenberg M. Going both ways: immune regulation via CD1d-dependent NKT cells. J Clin Invest (2004) 114:1379-88. doi:10.1172/ JCI23594

65. King IL, Fortier A, Tighe M, Dibble J, Watts GF, Veerapen N, et al. Invariant natural killer $\mathrm{T}$ cells direct $\mathrm{B}$ cell responses to cognate lipid antigen in an IL-21-dependent manner. Nat Immunol (2011) 13:44-50. doi:10.1038/ni.2172

66. McNab FW, Berzins SP, Pellicci DG, Kyparissoudis K, Field K, Smyth MJ, et al. The influence of CD1d in postselection NKT cell maturation and homeostasis. J Immunol (2005) 175:3762-8. doi:10.4049/jimmunol.175.6.3762

67. Matsuda JL, Gapin L, Sidobre S, Kieper WC, Tan JT, Ceredig R, et al. Homeostasis of V $\alpha 14$ i NKT cells. Nat Immunol (2002) 3:966-74. doi:10.1038/ni837

68. Wei DG, Lee H, Park SH, Beaudoin L, Teyton L, Lehuen A, et al. Expansion and long-range differentiation of the NKT cell lineage in mice expressing CD1d exclusively on cortical thymocytes. J Exp Med (2005) 202:239-48. doi:10.1084/ jem.20050413

69. Ranson T, Vosshenrich CA, Corcuff E, Richard O, Laloux V, Lehuen A, et al. IL-15 availability conditions homeostasis of peripheral natural killer T cells. Proc Natl Acad Sci U S A (2003) 100:2663-8. doi:10.1073/pnas.0535482100

70. Kennedy MK, Glaccum M, Brown SN, Butz EA, Viney JL, Embers M, et al. Reversible defects in natural killer and memory CD8 T cell lineages in interleukin 15-deficient mice. J Exp Med (2000) 191:771-80. doi:10.1084/jem.191. 5.771

71. Akbari O, Stock P, Meyer EH, Freeman GJ, Sharpe AH, Umetsu DT, et al. ICOS/ICOSL interaction is required for $\mathrm{CD}^{+}$invariant NKT cell function and homeostatic survival. J Immunol (2008) 180:5448-56. doi:10.4049/ jimmunol.180.8.5448

72. Stanic AK, Bezbradica JS, Park JJ, Van Kaer L, Boothby MR, Joyce S. Cutting edge: the ontogeny and function of $\mathrm{V} \alpha 14 \mathrm{~J} \alpha 18$ natural $\mathrm{T}$ lymphocytes require signal processing by protein kinase $\mathrm{C} \theta$ and NF- $\mathrm{KB}$. J Immunol (2004) 172:4667-71. doi:10.4049/jimmunol.172.8.4667

73. Townsend MJ, Weinmann AS, Matsuda JL, Salomon R, Farnham PJ, Biron $\mathrm{CA}$, et al. T-bet regulates the terminal maturation and homeostasis of NK and Vo14i NKT cells. Immunity (2004) 20:477-94. doi:10.1016/S1074-7613(04) 00076-7

74. Matsuda JL, Zhang Q, Ndonye R, Richardson SK, Howell AR, Gapin L. T-bet concomitantly controls migration, survival, and effector functions during the development of Vo14i NKT cells. Blood (2006) 107:2797-805. doi:10.1182/ blood-2005-08-3103

75. Dose M, Sleckman BP, Han J, Bredemeyer AL, Bendelac A, Gounari F. Intrathymic proliferation wave essential for $\mathrm{V} \alpha 14^{+}$natural killer $\mathrm{T}$ cell development depends on c-Myc. Proc Natl Acad Sci U S A (2009) 106:8641-6. doi:10.1073/pnas.0812255106

76. Mycko MP, Ferrero I, Wilson A, Jiang W, Bianchi T, Trumpp A, et al. Selective requirement for c-Myc at an early stage of V $\alpha 14$ i NKT cell development. $J$ Immunol (2009) 182:4641-8. doi:10.4049/jimmunol.0803394

77. Prevot N, Pyaram K, Bischoff E, Sen JM, Powell JD, Chang CH. Mammalian target of rapamycin complex 2 regulates invariant NKT cell development and function independent of promyelocytic leukemia zinc-finger. J Immunol (2015) 194:223-30. doi:10.4049/jimmunol.1401985

78. Lazarevic V, Zullo AJ, Schweitzer MN, Staton TL, Gallo EM, Crabtree GR, et al. The gene encoding early growth response 2 , a target of the transcription factor NFAT, is required for the development and maturation of natural killer $\mathrm{T}$ cells. Nat Immunol (2009) 10:306-13. doi:10.1038/ni.1696

79. Monticelli LA, Yang Y, Knell J, D'Cruz LM, Cannarile MA, Engel I, et al. Transcriptional regulator Id2 controls survival of hepatic NKT cells. Proc Natl Acad Sci U S A (2009) 106:19461-6. doi:10.1073/pnas.0908249106

80. Stanic AK, Bezbradica JS, Park JJ, Matsuki N, Mora AL, Van Kaer L, et al. $\mathrm{NF}-\kappa \mathrm{B}$ controls cell fate specification, survival, and molecular differentiation of immunoregulatory natural T lymphocytes. J Immunol (2004) 172:2265-73. doi:10.4049/jimmunol.172.4.2265
81. Gordy LE, Bezbradica JS, Flyak AI, Spencer CT, Dunkle A, Sun J, et al. IL-15 regulates homeostasis and terminal maturation of NKT cells. J Immunol (2011) 187:6335-45. doi:10.4049/jimmunol.1003965

82. Ohteki T, Ho S, Suzuki H, Mak TW, Ohashi PS. Role for IL-15/IL-15 receptor $\beta$-chain in natural killer $1.1^{+} \mathrm{T}$ cell receptor $\alpha \beta^{+}$cell development. J Immunol (1997) 159:5931-5.

83. Boesteanu A, De Silva AD, Nakajima H, Leonard WJ, Peschon JJ, Joyce S. Distinct roles for signals relayed through the common cytokine receptor $\gamma$ chain and interleukin 7 receptor $\alpha$ chain in natural T cell development. J Exp Med (1997) 186:331-6. doi:10.1084/jem.186.2.331

84. Lodolce JP, Boone DL, Chai S, Swain RE, Dassopoulos T, Trettin S, et al. IL-15 receptor maintains lymphoid homeostasis by supporting lymphocyte homing and proliferation. Immunity (1998) 9:669-76. doi:10.1016/S1074-7613(00) 80664-0

85. Chang CL, Lai YG, Hou MS, Huang PL, Liao NS. IL-15R $\alpha$ of radiationresistant cells is necessary and sufficient for thymic invariant NKT cell survival and functional maturation. J Immunol (2011) 187:1235-42. doi:10.4049/ jimmunol.1100270

86. Matloubian M, David A, Engel S, Ryan JE, Cyster JG. A transmembrane CXC chemokine is a ligand for HIV-coreceptor Bonzo. Nat Immunol (2000) 1:298-304. doi:10.1038/79738

87. Kim CH, Johnston B, Butcher EC. Trafficking machinery of NKT cells: shared and differential chemokine receptor expression among $\mathrm{V} \alpha 24^{+} \mathrm{V} \beta 11^{+} \mathrm{NKT}$ cell subsets with distinct cytokine-producing capacity. Blood (2002) 100:11-6. doi:10.1182/blood-2001-12-0196

88. Johnston B, Kim CH, Soler D, Emoto M, Butcher EC. Differential chemokine responses and homing patterns of murine TCR $\alpha \beta$ NKT cell subsets. $J$ Immunol (2003) 171:2960-9. doi:10.4049/jimmunol.171.6.2960

89. Thomas SY, Hou R, Boyson JE, Means TK, Hess C, Olson DP, et al. CD1drestricted NKT cells express a chemokine receptor profile indicative of Th1type inflammatory homing cells. J Immunol (2003) 171:2571-80. doi:10.4049/ jimmunol.171.5.2571

90. Geissmann F, Cameron TO, Sidobre S, Manlongat N, Kronenberg M, Briskin $\mathrm{MJ}$, et al. Intravascular immune surveillance by $\mathrm{CXCR} 6^{+} \mathrm{NKT}$ cells patrolling liver sinusoids. PLoS Biol (2005) 3:e113. doi:10.1371/journal.pbio.0030113

91. Germanov E, Veinotte L, Cullen R, Chamberlain E, Butcher EC, Johnston B. Critical role for the chemokine receptor CXCR6 in homeostasis and activation of CD1d-restricted NKT cells. J Immunol (2008) 181:81-91. doi:10.4049/ jimmunol.181.1.81

92. Shimaoka T, Seino K, Kume N, Minami M, Nishime C, Suematsu M, et al. Critical role for CXC chemokine ligand 16 (SR-PSOX) in Th1 response mediated by NKT cells. J Immunol (2007) 179:8172-9. doi:10.4049/jimmunol.179. 12.8172

93. Ajuebor MN, Aspinall AI, Zhou F, Le T, Yang Y, Urbanski SJ, et al. Lack of chemokine receptor CCR5 promotes murine fulminant liver failure by preventing the apoptosis of activated CD1d-restricted NKT cells. J Immunol (2005) 174:8027-37. doi:10.4049/jimmunol.174.12.8027

94. Murooka TT, Wong MM, Rahbar R, Majchrzak-Kita B, Proudfoot AE, Fish EN. CCL5-CCR5-mediated apoptosis in T cells: requirement for glycosaminoglycan binding and CCL5 aggregation. J Biol Chem (2006) 281:25184-94. doi:10.1074/jbc.M603912200

95. Algeciras-Schimnich A, Vlahakis SR, Villasis-Keever A, Gomez T, Heppelmann CJ, Bou G, et al. CCR5 mediates Fas- and caspase-8 dependent apoptosis of both uninfected and HIV infected primary human CD4 T cells. AIDS (2002) 16:1467-78. doi:10.1097/00002030-200207260-00003

96. Olszak T, An D, Zeissig S, Vera MP, Richter J, Franke A, et al. Microbial exposure during early life has persistent effects on natural killer $\mathrm{T}$ cell function. Science (2012) 336:489-93. doi:10.1126/science.1219328

97. Wei B, Wingender G, Fujiwara D, Chen DY, McPherson M, Brewer S, et al. Commensal microbiota and $\mathrm{CD}^{+} \mathrm{T}$ cells shape the formation of invariant NKT cells. J Immunol (2010) 184:1218-26. doi:10.4049/jimmunol.0902620

98. Wingender G, Stepniak D, Krebs P, Lin L, McBride S, Wei B, et al. Intestinal microbes affect phenotypes and functions of invariant natural killer $\mathrm{T}$ cells in mice. Gastroenterology (2012) 143:418-28. doi:10.1053/j.gastro.2012.04.017

99. Huttenhower C, Gevers D, Knight R, Abubucker S, Badger JH, Chinwalla AT, et al. Structure, function and diversity of the healthy human microbiome. Nature (2012) 486:207-14. doi:10.1038/nature11234

100. Wieland Brown LC, Penaranda C, Kashyap PC, Williams BB, Clardy J, Kronenberg $\mathrm{M}$, et al. Production of $\alpha$-galactosylceramide by a prominent member of 
the human gut microbiota. PLoS Biol (2013) 11:e1001610. doi:10.1371/journal. pbio. 1001610

101. An D, Oh SF, Olszak T, Neves JF, Avci FY, Erturk-Hasdemir D, et al. Sphingolipids from a symbiotic microbe regulate homeostasis of host intestinal natural killer T cells. Cell (2014) 156:123-33. doi:10.1016/j.cell.2013.11.042

102. Nieuwenhuis EE, Matsumoto T, Lindenbergh D, Willemsen R, Kaser A, Simons-Oosterhuis $\mathrm{Y}$, et al. CD1d-dependent regulation of bacterial colonization in the intestine of mice. J Clin Invest (2009) 119:1241-50. doi:10.1172/ JCI36509DS1

103. Olszak T, Neves JF, Dowds CM, Baker K, Glickman J, Davidson NO, et al. Protective mucosal immunity mediated by epithelial CD1d and IL-10. Nature (2014) 509:497-502. doi:10.1038/nature 13150

104. Pellicci DG, Hammond KJ, Uldrich AP, Baxter AG, Smyth MJ, Godfrey DI. A natural killer T (NKT) cell developmental pathway involving a thymusdependent NK1.1 ${ }^{-} \mathrm{CD} 4{ }^{+} \mathrm{CD} 1 \mathrm{~d}$-dependent precursor stage. J Exp Med (2002) 195:835-44. doi:10.1084/jem.20011544

105. Eberl G, Lees R, Smiley ST, Taniguchi M, Grusby MJ, MacDonald HR. Tissuespecific segregation of CD1d-dependent and CD1d-independent NK T cells. J Immunol (1999) 162:6410-9.

106. Hammond KJ, Pellicci DG, Poulton LD, Naidenko O, Scalzo AA, Baxter AG, et al. CD1d-restricted NKT cells: an interstrain comparison. J Immunol (2001) 167:1164-73. doi:10.4049/jimmunol.167.3.1164

107. Laloux V, Beaudoin L, Ronet C, Lehuen A. Phenotypic and functional differences between NKT cells colonizing splanchnic and peripheral lymph nodes. J Immunol (2002) 168:3251-8. doi:10.4049/jimmunol.168.7.3251

108. Scanlon ST, Thomas SY, Ferreira CM, Bai L, Krausz T, Savage PB, et al. Airborne lipid antigens mobilize resident intravascular NKT cells to induce allergic airway inflammation. J Exp Med (2011) 208:2113-24. doi:10.1084/jem. 20110522

109. Kim JH, Choi EY, Chung DH. Donor bone marrow type II (non-V $\alpha 14 \mathrm{~J} \alpha 18$ CD1d-restricted) NKT cells suppress graft-versus-host disease by producing IFN- $\gamma$ and IL-4. J Immunol (2007) 179:6579-87. doi:10.4049/jimmunol.179. 10.6579

110. Thomas SY, Scanlon ST, Griewank KG, Constantinides MG, Savage AK, Barr $\mathrm{KA}$, et al. PLZF induces an intravascular surveillance program mediated by long-lived LFA-1-ICAM-1 interactions. J Exp Med (2011) 208:1179-88. doi:10. $1084 / \mathrm{jem} .20102630$

111. Sandberg JK, Stoddart CA, Brilot F, Jordan KA, Nixon DF. Development of innate $\mathrm{CD}^{+} \alpha$-chain variable gene segment $24(\mathrm{~V} \alpha 24)$ natural killer T cells in the early human fetal thymus is regulated by IL-7. Proc Natl Acad Sci U S A (2004) 101:7058-63. doi:10.1073/pnas.0305986101

112. Berzins SP, Cochrane AD, Pellicci DG, Smyth MJ, Godfrey DI. Limited correlation between human thymus and blood NKT cell content revealed by an ontogeny study of paired tissue samples. Eur J Immunol (2005) 35:1399-407. doi:10.1002/eji.200425958

113. Loh L, Ivarsson MA, Michaëlsson J, Sandberg JK, Nixon DF. Invariant natural killer T cells developing in the human fetus accumulate and mature in the small intestine. Mucosal Immunol (2014) 7:1233-43. doi:10.1038/mi.2014.13

114. Kita H, Naidenko O, Kronenberg M, Ansari AA, Rogers P, He X, et al. Quantitation and phenotypic analysis of natural killer $\mathrm{T}$ cells in primary biliary cirrhosis using a human CD1d tetramer. Gastroenterology (2002) 123:1031-43. doi:10.1053/gast.2002.36020

115. Kenna T, Golden-Mason L, Porcelli SA, Koezuka Y, Hegarty JE, O’Farrelly $\mathrm{C}$, et al. NKT cells from normal and tumor-bearing human livers are phenotypically and functionally distinct from murine NKT cells. J Immunol (2003) 171:1775-9. doi:10.4049/jimmunol.171.4.1775

116. Lee PT, Benlagha K, Teyton L, Bendelac A. Distinct functional lineages of human Vo24 natural killer T cells. J Exp Med (2002) 195:637-41. doi:10.1084/ jem. 20011908

117. Chan AC, Serwecinska L, Cochrane A, Harrison LC, Godfrey DI, Berzins SP. Immune characterization of an individual with an exceptionally high natural killer $\mathrm{T}$ cell frequency and her immediate family. Clin Exp Immunol (2009) 156:238-45. doi:10.1111/j.1365-2249.2009.03888.x

118. Lee PT, Putnam A, Benlagha K, Teyton L, Gottlieb PA, Bendelac A. Testing the NKT cell hypothesis of human IDDM pathogenesis. J Clin Invest (2002) 110:793-800. doi:10.1172/JCI15832

119. Crough T, Purdie DM, Okai M, Maksoud A, Nieda M, Nicol AJ. Modulation of human $\mathrm{V} \alpha 24^{+} \mathrm{V} \beta 11^{+}$NKT cells by age, malignancy and conventional anticancer therapies. BrJ Cancer (2004) 91:1880-6. doi:10.1038/sj.bjc.6602218
120. Motohashi S, Kobayashi S, Ito T, Magara KK, Mikuni O, Kamada N, et al. Preserved IFN- $\alpha$ production of circulating V $\alpha 24$ NKT cells in primary lung cancer patients. Int J Cancer (2002) 102:159-65. doi:10.1002/ijc.10678

121. Kawano T, Nakayama T, Kamada N, Kaneko Y, Harada M, Ogura N, et al. Antitumor cytotoxicity mediated by ligand-activated human V $\alpha 24$ NKT cells. Cancer Res (1999) 59:5102-5.

122. Tahir SM, Cheng O, Shaulov A, Koezuka Y, Bubley GJ, Wilson SB, et al. Loss of IFN- $\gamma$ production by invariant NK T cells in advanced cancer. J Immunol (2001) 167:4046-50. doi:10.4049/jimmunol.167.7.4046

123. Takahashi T, Chiba S, Nieda M, Azuma T, Ishihara S, Shibata $\mathrm{Y}$, et al. Cutting edge: analysis of human $\mathrm{V} \alpha 24^{+} \mathrm{CD} 8^{+} \mathrm{NK} \mathrm{T}$ cells activated by $\alpha$-galactosylceramide-pulsed monocyte-derived dendritic cells. J Immunol (2002) 168:3140-4. doi:10.4049/jimmunol.168.7.3140

124. Chan AC, Leeansyah E, Cochrane A, d'Udekem d'Acoz Y, Mittag D, Harrison LC, et al. Ex-vivo analysis of human natural killer T cells demonstrates heterogeneity between tissues and within established $\mathrm{CD} 4^{+}$and $\mathrm{CD} 4^{-}$subsets. Clin Exp Immunol (2013) 172:129-37. doi:10.1111/cei.12045

125. Emoto M, Zerrahn J, Miyamoto M, Pérarnau B, Kaufmann SH. Phenotypic characterization of $\mathrm{CD}^{+}{ }^{+}$NKT cells. Eur J Immunol (2000) 30:2300-11. doi:10. 1002/1521-4141(2000)30:8

126. Akbari O, Stock P, Meyer E, Kronenberg M, Sidobre S, Nakayama T, et al. Essential role of NKT cells producing IL-4 and IL-13 in the development of allergen-induced airway hyperreactivity. Nat Med (2003) 9:582-8. doi:10. $1038 / \mathrm{nm} 851$

127. Akbari O, Faul JL, Hoyte EG, Berry GJ, Wahlstrom J, Kronenberg M, et al. $\mathrm{CD}^{+}$invariant T-cell-receptor ${ }^{+}$natural killer T cells in bronchial asthma. $\mathrm{N}$ Engl J Med (2006) 354:1117-29. doi:10.1056/NEJMoa053614

128. Crowe NY, Coquet JM, Berzins SP, Kyparissoudis K, Keating R, Pellicci DG, et al. Differential antitumor immunity mediated by NKT cell subsets in vivo. $J$ Exp Med (2005) 202:1279-88. doi:10.1084/jem.20050953

129. Chang PP, Barral P, Fitch J, Pratama A, Ma CS, Kallies A, et al. Identification of Bcl-6-dependent follicular helper NKT cells that provide cognate help for B cell responses. Nat Immunol (2011) 13:35-43. doi:10.1038/ni.2166

130. Johnston B, Butcher EC. Chemokines in rapid leukocyte adhesion triggering and migration. Semin Immunol (2002) 14:83-92. doi:10.1006/smim.2001.0345

131. Stein JV, Rot A, Luo Y, Narasimhaswamy M, Nakano H, Gunn MD, et al. The CC chemokine thymus-derived chemotactic agent 4 (TCA-4, secondary lymphoid tissue chemokine, 6Ckine, exodus-2) triggers lymphocyte functionassociated antigen 1-mediated arrest of rolling $\mathrm{T}$ lymphocytes in peripheral lymph node high endothelial venules. J Exp Med (2000) 191:61-76. doi:10. 1084/jem.191.1.61

132. Warnock RA, Askari S, Butcher EC, Andrian UH. Molecular mechanisms of lymphocyte homing to peripheral lymph nodes. J Exp Med (1998) 187:205-16. doi:10.1084/jem.187.2.205

133. Hamann A, Andrew DP, Jablonski-Westrich D, Hoizmann B, Butcher EC. Role of $\alpha 4$-integrins in lymphocyte homing to mucosal tissues in vivo. J Immunol (1994) 152:3282-93.

134. Kunkel EJ, Campbell JJ, Haraldsen G, Pan J, Boisvert J, Roberts AI, et al. Lymphocyte CC chemokine receptor 9 and epithelial thymus-expressed chemokine (TECK) expression distinguish the small intestinal immune compartment: epithelial expression of tissue-specific chemokines as an organizing principle in regional immunity. J Exp Med (2000) 192:761-8. doi:10.1084/jem. 192.5.761

135. Soler D, Humphreys TL, Spinola SM, Campbell JJ. CCR4 versus CCR10 in human cutaneous TH lymphocyte trafficking. Blood (2003) 101:1677-83. doi:10.1182/blood-2002-07-2348

136. Kunkel EJ, Butcher EC. Chemokines and the tissue-specific migration of lymphocytes. Immunity (2002) 16:1-4. doi:10.1016/S1074-7613(01)00261-8

137. Kim CH, Rott L, Kunkel EJ, Genovese MC, Andrew DP, Wu L, et al. Rules of chemokine receptor association with $\mathrm{T}$ cell polarization in vivo. J Clin Invest (2001) 108:1331-9. doi:10.1172/JCI13543

138. Kim CH, Butcher EC, Johnston B. Distinct subsets of human V $\alpha 24$-invariant NKT cells: cytokine responses and chemokine receptor expression. Trends Immunol (2002) 23:516-9. doi:10.1016/S1471-4906(02)02323-2

139. Schaerli P, Ebert L, Willimann K, Blaser A, Roos RS, Loetscher P, et al. A skinselective homing mechanism for human immune surveillance T cells. $J$ Exp Med (2004) 199:1265-75. doi:10.1084/jem.20032177

140. Harner S, Noessner E, Nadas K, Leumann-Runge A, Schiemann M, Faber FL, et al. Cord blood V $\alpha 24$-V $\beta 11$ natural killer $\mathrm{T}$ cells display a Th2-chemokine 
receptor profile and cytokine responses. PLoS One (2011) 6:e15714. doi:10. 1371/journal.pone.0015714

141. Rolf J, Berntman E, Stenström M, Smith EM, Månsson R, Stenstad H, et al. Molecular profiling reveals distinct functional attributes of CD1d-restricted natural killer (NK) T cell subsets. Mol Immunol (2008) 45:2607-20. doi:10. 1016/j.molimm.2007.12.022

142. Lin H, Nieda M, Hutton JF, Rozenkov V, Nicol AJ. Comparative gene expression analysis of NKT cell subpopulations. J Leukoc Biol (2006) 80:164-73. doi:10.1189/jlb.0705421.0741-5400/06/0080- 164

143. Kim CH, Pelus LM, White JR, Broxmeyer HE. Differential chemotactic behavior of developing T cells in response to thymic chemokines. Blood (1998) 91:4434-43.

144. Campbell JJ, Pan J, Butcher EC. Cutting edge: developmental switches in chemokine responses during T cell maturation. J Immunol (1999) 163:2353-7.

145. Bleul CC, Boehm T. Chemokines define distinct microenvironments in the developing thymus. Eur J Immunol (2000) 30:3371-9. doi:10.1002/ 1521-4141(2000012)30:12

146. Uehara S, Song K, Farber JM, Love PE. Characterization of CCR9 expression and CCL25/thymus-expressed chemokine responsiveness during T cell development: $\mathrm{CD} 3^{\text {high }} \mathrm{CD} 69^{+}$thymocytes and $\gamma \delta \mathrm{TCR}^{+}$thymocytes preferentially respond to CCL25. J Immunol (2002) 168:134-42. doi:10.4049/jimmunol.168. 1.134

147. Coles MC, Raulet DH. NK1.1 ${ }^{+} \mathrm{T}$ cells in the liver arise in the thymus and are selected by interactions with class I molecules on $\mathrm{CD} 4^{+} \mathrm{CD} 8^{+}$cells. J Immunol (2000) 164:2412-8. doi:10.4049/jimmunol.164.5.2412

148. Cowan JE, McCarthy NI, Parnell SM, White AJ, Bacon A, Serge A, et al. Differential requirement for CCR4 and CCR7 during the development of innate and adaptive $\alpha \beta$ T cells in the adult thymus. J Immunol (2014) 193:1204-12. doi:10.4049/jimmunol.1400993

149. White AJ, Jenkinson WE, Cowan JE, Parnell SM, Bacon A, Jones ND, et al. An essential role for medullary thymic epithelial cells during the intrathymic development of invariant NKT cells. J Immunol (2014) 192:2659-66. doi:10. 4049/jimmunol.1303057

150. Berzins SP, McNab FW, Jones CM, Smyth MJ, Godfrey DI. Long-term retention of mature NK1.1 ${ }^{+}$NKT cells in the thymus. J Immunol (2006) 176:4059-65. doi:10.4049/jimmunol.176.7.4059

151. Drennan MB, Franki AS, Dewint P, Van Beneden K, Seeuws S, van de Pavert SA, et al. Cutting edge: the chemokine receptor CXCR3 retains invariant NK $\mathrm{T}$ cells in the thymus. J Immunol (2009) 183:2213-6. doi:10.4049/jimmunol. 0901213

152. Berzins SP, Uldrich AP, Pellicci DG, McNab FW, Hayakawa Y, Smyth MJ, et al. Parallels and distinctions between T and NKT cell development in the thymus. Immunol Cell Biol (2004) 82:269-75. doi:10.1111/j.1440-1711.2004.01256.x

153. Wilbanks A, Zondlo SC, Murphy K, Mak S, Soler D, Langdon P, et al. Expression cloning of the STRL33/BONZO/TYMSTR ligand reveals elements of CC, CXC, and CX3C chemokines. J Immunol (2001) 166:5145-54. doi:10.4049/ jimmunol.166.8.5145

154. Kim CH, Kunkel EJ, Boisvert J, Johnston B, Campbell JJ, Genovese MC, et al. Bonzo/CXCR6 expression defines type 1-polarized T-cell subsets with extralymphoid tissue homing potential. J Clin Invest (2001) 107:595-601. doi:10.1172/JCI11902

155. Lim HW, Lee J, Hillsamer P, Kim CH. Human Th17 cells share major trafficking receptors with both polarized effector T cells and FOXP $3^{+}$regulatory $\mathrm{T}$ cells. J Immunol (2008) 180:122-9. doi:10.4049/jimmunol.180.1.122

156. Slauenwhite D, Gebremeskel S, Doucette CD, Hoskin DW, Johnston B. Regulation of cytokine polarization and $\mathrm{T}$ cell recruitment to inflamed paws in mouse collagen-induced arthritis by the chemokine receptor CXCR6. Arthritis Rheumatol (2014) 66:3001-12. doi:10.1002/art.38816

157. Emoto M, Mittrücker HW, Schmits R, Mak TW, Kaufmann SH. Critical role of leukocyte function-associated antigen-1 in liver accumulation of $\mathrm{CD} 4{ }^{+} \mathrm{NKT}$ cells. J Immunol (1999) 162:5094-8.

158. Ohteki T, Maki C, Koyasu S, Mak TW, Ohashi PS. Cutting edge: LFA-1 is required for liver NK1.1 ${ }^{+}$TCR $\alpha \beta^{+}$cell development: evidence that liver NK1.1 ${ }^{+}$TCR $\alpha \beta^{+}$cells originate from multiple pathways. J Immunol (1999) 162:3753-6.

159. Semmling V, Lukacs-Kornek V, Thaiss CA, Quast T, Hochheiser K, Panzer U, et al. Alternative cross-priming through CCL17-CCR4-mediated attraction of CTLs toward NKT cell-licensed DCs. Nat Immunol (2010) 11:313-20. doi:10. 1038/ni.1848
160. Meyer EH, Wurbel MA, Staton TL, Pichavant M, Kan MJ, Savage PB, et al. iNKT cells require CCR4 to localize to the airways and to induce airway hyperreactivity. J Immunol (2007) 179:4661-71. doi:10.4049/jimmunol.179.7. 4661

161. Kastenmüller W, Torabi-Parizi P, Subramanian N, Lämmermann T, Germain RN. A spatially-organized multicellular innate immune response in lymph nodes limits systemic pathogen spread. Cell (2012) 150:1235-48. doi:10.1016/ j.cell.2012.07.021

162. Barral P, Polzella P, Bruckbauer A, van Rooijen N, Besra GS, Cerundolo V, et al. $\mathrm{CD} 169^{+}$macrophages present lipid antigens to mediate early activation of iNKT cells in lymph nodes. Nat Immunol (2010) 11:303-12. doi:10.1038/ni. 1853

163. Rachitskaya AV, Hansen AM, Horai R, Li Z, Villasmil R, Luger D, et al. Cutting edge: NKT cells constitutively express IL-23 receptor and ROR $\gamma \mathrm{t}$ and rapidly produce IL-17 upon receptor ligation in an IL-6independent fashion. J Immunol (2008) 180:5167-71. doi:10.4049/jimmunol. 180.8.5167

164. Michel M, Mendes-da-Cruz D, Keller AC, Lochner M, Schneider E, Dy M, et al. Critical role of ROR- $\gamma \mathrm{t}$ in a new thymic pathway leading to IL-17producing invariant NKT cell differentiation. Proc Natl Acad Sci U S A (2008) 105:19845-50. doi:10.1073/pnas.0806472105

165. Hirota K, Yoshitomi H, Hashimoto M, Maeda S, Teradaira S, Sugimoto N, et al. Preferential recruitment of CCR6-expressing Th17 cells to inflamed joints via CCL20 in rheumatoid arthritis and its animal model. J Exp Med (2007) 204:2803-12. doi:10.1084/jem.20071397

166. Katchar K, Kelly CP, Keates S, O’Brien MJ, Keates AC. MIP-3 $\alpha$ neutralizing monoclonal antibody protects against TNBS-induced colonic injury and inflammation in mice. Am J Physiol Gastrointest Liver Physiol (2007) 292:G1263-71. doi:10.1152/ajpgi.00409.2006

167. Moreira-Teixeira L, Resende M, Coffre M, Devergne O, Herbeuval JP, Hermine $\mathrm{O}$, et al. Proinflammatory environment dictates the IL-17-producing capacity of human invariant NKT cells. J Immunol (2011) 186:5758-65. doi:10. 4049/jimmunol.1003043

168. Monteiro M, Almeida CF, Agua-Doce A, Graca L. Induced IL-17-producing invariant NKT cells require activation in presence of TGF- $\beta$ and IL-1 $\beta$. $J$ Immunol (2013) 190:805-11. doi:10.4049/jimmunol.1201010

169. Forster R, Mattis AE, Kremmer E, Wolf E, Brem G, Lipp M. A putative chemokine receptor, BLR1, directs B cell migration to defined lymphoid organs and specific anatomic compartments of the spleen. Cell (1996) 87:1037-47. doi:10.1016/S0092-8674(00)81798-5

170. Reif K, Ekland EH, Ohl L, Nakano H, Lipp M, Forster R, et al. Balanced responsiveness to chemoattractants from adjacent zones determines B-cell position. Nature (2002) 416:94-9. doi:10.1038/416094a

171. Campbell DJ, Kim CH, Butcher EC. Separable effector T cell populations specialized for B cell help or tissue inflammation. Nat Immunol (2001) 2:876-81. doi:10.1038/ni0901-876

172. Kim CH, Rott LS, Clark-Lewis I, Campbell DJ, Wu L, Butcher EC. Subspecialization of $\mathrm{CXCR}^{+} \mathrm{T}$ cells: B helper activity is focused in a germinal center-localized subset of CXCR5 ${ }^{+}$T cells. J Exp Med (2001) 193:1373-81. doi:10.1084/jem.193.12.1373

173. Tonti E, Fedeli M, Napolitano A, Iannacone M, von Andrian UH, Guidotti LG, et al. Follicular helper NKT cells induce limited B cell responses and germinal center formation in the absence of $\mathrm{CD} 4^{+} \mathrm{T}$ cell help. J Immunol (2012) 188:3217-22. doi:10.4049/jimmunol.1103501

174. Leadbetter EA, Brigl M, Illarionov P, Cohen N, Luteran MC, Pillai S, et al. NK T cells provide lipid antigen-specific cognate help for B cells. Proc Natl Acad Sci U S A (2008) 105:8339-44. doi:10.1073/pnas.0801375105

175. King IL, Amiel E, Tighe M, Mohrs K, Veerapen N, Besra G, et al. The mechanism of splenic invariant NKT cell activation dictates localization in vivo. $J$ Immunol (2013) 191:572-82. doi:10.4049/jimmunol.1300299

176. Barral P, Sánchez-Niño MD, van Rooijen N, Cerundolo V, Batista FD. The location of splenic NKT cells favours their rapid activation by blood-borne antigen. EMBO J (2012) 31:2378-90. doi:10.1038/emboj.2012.87

177. Wong CH, Kubes P. Imaging natural killer T cells in action. Immunol Cell Biol (2013) 91:304-10. doi:10.1038/icb.2013.6

178. Sköld M, Behar SM. Role of CD1d-restricted NKT cells in microbial immunity. Infect Immun (2003) 71:5447-55. doi:10.1128/IAI.71.10.5447

179. Brigl M, Brenner MB. CD1: antigen presentation and T cell function. Annu Rev Immunol (2004) 22:817-90. doi:10.1146/annurev.immunol.22.012703.104608 
180. Yu KO, Porcelli SA. The diverse functions of CD1d-restricted NKT cells and their potential for immunotherapy. Immunol Lett (2005) 100:42-55. doi:10. 1016/j.imlet.2005.06.010

181. Fischer K, Scotet E, Niemeyer M, Koebernick H, Zerrahn J, Maillet S, et al. Mycobacterial phosphatidylinositol mannoside is a natural antigen for CD1drestricted T cells. Proc Natl Acad Sci U S A (2004) 101:10685-90. doi:10.1073/ pnas.0403787101

182. Kinjo Y, Wu D, Kim G, Xing GW, Poles MA, Ho DD, et al. Recognition of bacterial glycosphingolipids by natural killer T cells. Nature (2005) 434:520-5. doi:10.1038/nature03407

183. Sriram V, Du W, Gervay-Hague J, Brutkiewicz RR. Cell wall glycosphingolipids of Sphingomonas paucimobilis are CD1d-specific ligands for NKT cells. Eur J Immunol (2005) 35:1692-701. doi:10.1002/eji.200526157

184. Mattner J, Debord KL, Ismail N, Goff RD, Cantu C, Zhou D, et al. Exogenous and endogenous glycolipid antigens activate NKT cells during microbial infections. Nature (2005) 434:525-9. doi:10.1038/nature03408

185. Kinjo Y, Tupin E, Wu D, Fujio M, Garcia-Navarro R, Benhnia MR, et al. Natural killer $\mathrm{T}$ cells recognize diacylglycerol antigens from pathogenic bacteria. Nat Immunol (2006) 7:978-86. doi:10.1038/ni1380

186. Chang Y, Kim HY, Albacker LA, Lee HH, Baumgarth N, Akira S, et al. Influenza infection in suckling mice expands an NKT cell subset that protects against airway hyperreactivity. J Clin Invest (2011) 121:57-69. doi:10.1172/ JCI44845DS1

187. Godfrey DI, Rossjohn J. New ways to turn on NKT cells. J Exp Med (2011) 208:1121-5. doi:10.1084/jem.20110983

188. Amprey JL, Im JS, Turco SJ, Murray HW, Illarionov PA, Besra GS, et al. A subset of liver NK T cells is activated during Leishmania donovani infection by CD1d-bound lipophosphoglycan. J Exp Med (2004) 200:895-904. doi:10. 1084/jem.20040704

189. Kinjo Y, Illarionov PA, Vela JL, Pei B, Girardi E, Li X, et al. Invariant natural killer T cells recognize glycolipids from pathogenic Gram-positive bacteria. Nat Immunol (2011) 12:966-74. doi:10.1038/ni.2096

190. Brigl M, Bry L, Kent SC, Gumperz JE, Brenner MB. Mechanism of CD1drestricted natural killer $\mathrm{T}$ cell activation during microbial infection. Nat Immunol (2003) 4:1230-7. doi:10.1038/ni1002

191. Paget C, Mallevaey T, Speak AO, Torres D, Fontaine J, Sheehan KC, et al. Activation of invariant NKT cells by toll-like receptor 9-stimulated dendritic cells requires type I interferon and charged glycosphingolipids. Immunity (2007) 27:597-609. doi:10.1016/j.immuni.2007.08.017

192. Salio M, Speak AO, Shepherd D, Polzella P, Illarionov PA, Veerapen N, et al. Modulation of human natural killer T cell ligands on TLR-mediated antigenpresenting cell activation. Proc Natl Acad Sci U S A (2007) 104:20490-5. doi:10.1073/pnas.0710145104

193. Nagarajan NA, Kronenberg M. Invariant NKT cells amplify the innate immune response to lipopolysaccharide. J Immunol (2007) 178:2706-13. doi:10.4049/ jimmunol.178.5.2706

194. Wang X, Bishop KA, Hegde S, Rodenkirch LA, Pike JW, Gumperz JE. Human invariant natural killer $\mathrm{T}$ cells acquire transient innate responsiveness via histone H4 acetylation induced by weak TCR stimulation. J Exp Med (2012) 209:987-1000. doi:10.1084/jem.20111024

195. Wesley JD, Tessmer MS, Chaukos D, Brossay L. NK cell-like behavior of Vo14i NK T cells during MCMV infection. PLoS Pathog (2008) 4:e1000106. doi:10.1371/journal.ppat.1000106

196. Velazquez P, Cameron TO, Kinjo Y, Nagarajan N, Kronenberg M, Dustin ML. Cutting edge: activation by innate cytokines or microbial antigens can cause arrest of natural killer T cell patrolling of liver sinusoids. J Immunol (2008) 180:2024-8. doi:10.4049/jimmunol.180.4.2024

197. Lee WY, Moriarty TJ, Wong CH, Zhou H, Strieter RM, van Rooijen N, et al. An intravascular immune response to Borrelia burgdorferi involves Kupffer cells and iNKT cells. Nat Immunol (2010) 11:295-302. doi:10.1038/ni.1855

198. Tupin E, Benhnia MR, Kinjo Y, Patsey R, Lena CJ, Haller MC, et al. NKT cells prevent chronic joint inflammation after infection with Borrelia burgdorferi. Proc Natl Acad Sci U S A (2008) 105:19863-8. doi:10.1073/pnas.0810519105

199. Lee WY, Sanz MJ, Wong CH, Hardy PO, Salman-Dilgimen A, Moriarty TJ, et al. Invariant natural killer $\mathrm{T}$ cells act as an extravascular cytotoxic barrier for joint-invading Lyme Borrelia. Proc Natl Acad Sci U S A (2014) 111:13936-41. doi:10.1073/pnas.1404769111

200. Katchar K, Drouin EE, Steere AC. Natural killer cells and natural killer T cells in Lyme arthritis. Arthritis Res Ther (2013) 15:R183. doi:10.1186/ar4373
201. Hahn DL, Azenabor AA, Beatty WL, Byrne GI. Chlamydia pneumoniae as a respiratory pathogen. Front Biosci (2002) 7:e66-76. doi:10.2741/hahn

202. Rank RG, Yeruva L. Hidden in plain sight: chlamydial gastrointestinal infection and its relevance to persistence in human genital infection. Infect Immun (2014) 82:1362-71. doi:10.1128/IAI.01244-13

203. LaVerda D, Albanese LN, Ruther PE, Morrison SG, Morrison RP, Ault KA, et al. Seroreactivity to Chlamydia trachomatis Hsp10 correlates with severity of human genital tract disease. Infect Immun (2000) 68:303-9. doi:10.1128/IAI. 68.1.303-309.2000

204. Zhang X, Pacheco-Tena C, Inman RD. Microbe hunting in the joints. Arthritis Rheum (2003) 49:479-82. doi:10.1002/art.11186

205. Bharhani MS, Chiu B, Na KS, Inman RD. Activation of invariant NKT cells confers protection against Chlamydia trachomatis-induced arthritis. Int Immunol (2009) 21:859-70. doi:10.1093/intimm/dxp052

206. Yang X. Natural killer T (NKT) cell subsets in chlamydial infections. Adv Exp Med Biol (2007) 601:243-6. doi:10.1007/978-0-387-72005-0_25

207. Wang H, Zhao L, Peng Y, Liu J, Qi M, Chen Q, et al. Protective role of $\alpha$ galactosylceramide-stimulated natural killer $\mathrm{T}$ cells in genital tract infection with Chlamydia muridarum. FEMS Immunol Med Microbiol (2012) 65:43-54. doi:10.1111/j.1574-695X.2012.00939.x

208. Jiang J, Karimi O, Ouburg S, Champion CI, Khurana A, Liu G, et al. Interruption of CXCL13-CXCR5 axis increases upper genital tract pathology and activation of NKT cells following chlamydial genital infection. PLoS One (2012) 7:e47487. doi:10.1371/journal.pone.0047487

209. Nakamatsu M, Yamamoto N, Hatta M, Nakasone C, Kinjo T, Miyagi K, et al. Role of interferon- $\gamma$ in $\mathrm{V} \alpha 14^{+}$natural killer $\mathrm{T}$ cell-mediated host defense against Streptococcus pneumoniae infection in murine lungs. Microbes Infect (2007) 9:364-74. doi:10.1016/j.micinf.2006.12.003

210. Holzapfel KL, Tyznik AJ, Kronenberg M, Hogquist KA. Antigen-dependent versus -independent activation of invariant NKT cells during infection. $J$ Immunol (2014) 192:5490-8. doi:10.4049/jimmunol.1400722

211. Moran AE, Holzapfel KL, Xing Y, Cunningham NR, Maltzman JS, Punt J, et al. $\mathrm{T}$ cell receptor signal strength in Treg and iNKT cell development demonstrated by a novel fluorescent reporter mouse. J Exp Med (2011) 208:1279-89. doi:10.1084/jem.20110308

212. Kawakami K, Kinjo Y, Uezu K, Yara S, Miyagi K, Koguchi Y, et al. Monocyte chemoattractant protein-1-dependent increase of Vo14 NKT cells in lungs and their roles in Th1 response and host defense in cryptococcal infection. J Immunol (2001) 167:6525-32. doi:10.4049/jimmunol.167.11.6525

213. Bai L, Deng S, Reboulet R, Mathew R, Teyton L, Savage PB, et al. Natural killer $\mathrm{T}$ (NKT)-B-cell interactions promote prolonged antibody responses and longterm memory to pneumococcal capsular polysaccharides. Proc Natl Acad Sci U S A (2013) 110:16097-102. doi:10.1073/pnas.1303218110

214. Herzig DS, Driver BR, Fang G, Toliver-Kinsky TE, Shute EN, Sherwood ER. Regulation of lymphocyte trafficking by CXC chemokine receptor 3 during septic shock. Am J Respir Crit Care Med (2012) 185:291-300. doi:10.1164/ rccm.201108-1560OC

215. Fusakio ME, Mohammed JP, Laumonnier Y, Hoebe K, Köhl J, Mattner J. C5a regulates NKT and NK cell functions in sepsis. J Immunol (2011) 187:5805-12. doi:10.4049/jimmunol.1100338

216. Chackerian A, Alt J, Perera V, Behar SM. Activation of NKT cells protects mice from tuberculosis. Infect Immun (2002) 70:6302-9. doi:10.1128/IAI.70. $11.6302-6309.2002$

217. Sada-Ovalle I, Chiba A, Gonzales A, Brenner MB, Behar SM. Innate invariant NKT cells recognize Mycobacterium tuberculosis-infected macrophages, produce interferon- $\gamma$, and kill intracellular bacteria. PLoS Pathog (2008) 4:e1000239. doi:10.1371/journal.ppat.1000239

218. Lee LN, Ronan EO, de Lara C, Franken KL, Ottenhoff TH, Tchilian EZ, et al. CXCR6 is a marker for protective antigen-specific cells in the lungs after intranasal immunization against Mycobacterium tuberculosis. Infect Immun (2011) 79:3328-37. doi:10.1128/IAI.01133-10

219. Mempel M, Ronet C, Suarez F, Gilleron M, Puzo G, Van Kaer L, et al. Natural killer $\mathrm{T}$ cells restricted by the monomorphic MHC class $1 \mathrm{~b}$ CD1d1 molecules behave like inflammatory cells. J Immunol (2002) 168:365-71. doi:10.4049/ jimmunol.168.1.365

220. Stolberg VR, Chiu B, Martin BE, Shah SA, Sandor M, Chensue SW. Cysteinecysteinyl chemokine receptor 6 mediates invariant natural killer T cell airway recruitment and innate stage resistance during mycobacterial infection. $J$ Innate Immun (2011) 3:99-108. doi:10.1159/000321156 
221. Jiang X, Zhang M, Lai Q, Huang X, Li Y, Sun J, et al. Restored circulating invariant NKT cells are associated with viral control in patients with chronic hepatitis B. PLoS One (2011) 6:e28871. doi:10.1371/journal.pone.0028871

222. Hadziyannis SJ, Vassilopoulos D, Hadziyannis E. The natural course of chronic hepatitis B virus infection and its management. Adv Pharmacol (2013) 67:247-91. doi:10.1016/B978-0-12-405880-4.00007-X

223. Tripathy AS, Das R, Chadha MS, Arankalle VA. Epidemic of hepatitis B with high mortality in India: association of fulminant disease with lack of CCL4 and natural killer T cells. J Viral Hepat (2011) 18:e415-22. doi:10.1111/j.1365-2893. 2011.01457.x

224. Li J, Han Y, Jin K, Wan Y, Wang S, Liu B, et al. Dynamic changes of cytotoxic T lymphocytes (CTLs), natural killer (NK) cells, and natural killer T (NKT) cells in patients with acute hepatitis B infection. Virol J (2011) 8:1-8. doi:10.1186/ 1743-422X-8-199

225. Inoue $M$, Kanto $T$, Miyatake $H$, Itose I, Miyazaki M, Yakushijin $T$, et al. Enhanced ability of peripheral invariant natural killer $\mathrm{T}$ cells to produce IL13 in chronic hepatitis C virus infection. J Hepatol (2006) 45:190-6. doi:10. 1016/j.jhep.2006.01.034

226. Apolinario A, Majano PL, Alvarez-Perez E, Saez A, Lozano C, Vargas J, et al. Increased expression of $\mathrm{T}$ cell chemokines and their receptors in chronic hepatitis C: relationship with the histological activity of liver disease. Am J Gastroenterol (2002) 97:2861-70. doi:10.1111/j.1572-0241.2002.07054.x

227. Harvey CE, Post JJ, Palladinetti P, Freeman AJ, Ffrench RA, Kumar RK, et al. Expression of the chemokine IP-10 (CXCL10) by hepatocytes in chronic hepatitis $\mathrm{C}$ virus infection correlates with histological severity and lobular inflammation. J Leukoc Biol (2003) 74:360-9. doi:10.1189/jlb.0303093

228. De Lalla C, Galli G, Aldrighetti L, Romeo R, Mariani M, Monno A, et al. Production of profibrotic cytokines by invariant NKT cells characterizes cirrhosis progression in chronic viral hepatitis. J Immunol (2004) 173:1417-25. doi:10.4049/jimmunol.173.2.1417

229. Matangkasombut P, Chan-In W, Opasawaschai A, Pongchaikul P, Tangthawornchaikul N, Vasanawathana S, et al. Invariant NKT cell response to dengue virus infection in human. PLoS Negl Trop Dis (2014) 8:e2955. doi:10.1371/ journal.pntd.0002955

230. Renneson J, Guabiraba R, Maillet I, Marques RE, Ivanov S, Fontaine J, et al. A detrimental role for invariant natural killer $\mathrm{T}$ cells in the pathogenesis of experimental dengue virus infection. Am J Pathol (2011) 179:1872-83. doi:10. 1016/j.ajpath.2011.06.023

231. St John AL, Rathore AP, Yap H, Ng ML, Metcalfe DD, Vasudevan SG, et al. Immune surveillance by mast cells during dengue infection promotes natural killer (NK) and NKT-cell recruitment and viral clearance. Proc Natl Acad Sci US A (2011) 108:9190-5. doi:10.1073/pnas.1105079108

232. Chen WW, Xie YX, Zhang YH, Feng YQ, Li BA, Li B, et al. [Changes and analysis of peripheral white blood cells and lymphocyte subsets for patients with pandemic influenza A virus (H1N1) infection]. Zhonghua Shi Yan He Lin Chuang Bing Du Xue Za Zhi (2010) 24:331-3.

233. Kok WL, Denney L, Benam K, Cole S, Clelland C, McMichael AJ, et al. Pivotal advance: invariant NKT cells reduce accumulation of inflammatory monocytes in the lungs and decrease immune-pathology during severe influenza A virus infection. J Leukoc Biol (2012) 91:357-68. doi:10.1189/jlb.0411184

234. Paget C, Ivanov S, Fontaine J, Blanc F, Pichavant M, Renneson J, et al. Potential role of invariant NKT cells in the control of pulmonary inflammation and $\mathrm{CD}^{+} \mathrm{T}$ cell response during acute influenza A virus $\mathrm{H} 3 \mathrm{~N} 2$ pneumonia. $J$ Immunol (2011) 186:5590-602. doi:10.4049/jimmunol.1002348

235. Ishikawa H, Tanaka K, Kutsukake E, Fukui T, Sasaki H, Hata A, et al. IFN- $\gamma$ production downstream of NKT cell activation in mice infected with influenza virus enhances the cytolytic activities of both NK cells and viral antigen-specific $\mathrm{CD}^{+} \mathrm{T}$ cells. Virology (2010) 407:325-32. doi:10.1016/j. virol.2010.08.030

236. De Santo C, Salio M, Masri SH, Lee LY, Dong T, Speak AO, et al. Invariant NKT cells reduce the immunosuppressive activity of influenza A virus-induced myeloid-derived suppressor cells in mice and humans. J Clin Invest (2008) 118:4036-48. doi:10.1172/JCI36264

237. Gebremeskel S, Clattenburg DR, Slauenwhite D, Lobert L, Johnston B. Natural killer $\mathrm{T}$ cell activation overcomes immunosuppression to enhance clearance of post-surgical breast cancer metastasis in mice. Oncoimmunology (2015) 4:e995562. doi:10.1080/2162402X.2014.995562

238. Ko SY, Ko HJ, Chang WS, Park SH, Kweon MN, Kang CY. $\alpha$ galactosylceramide can act as a nasal vaccine adjuvant inducing protective immune responses against viral infection and tumor. J Immunol (2005) 175:3309-17. doi:10.4049/jimmunol.175.5.3309

239. Youn HJ, Ko SY, Lee KA, Ko HJ, Lee YS, Fujihashi K, et al. A single intranasal immunization with inactivated influenza virus and $\alpha$-galactosylceramide induces long-term protective immunity without redirecting antigen to the central nervous system. Vaccine (2007) 25:5189-98. doi:10.1016/j.vaccine. 2007.04.081

240. Guillonneau C, Mintern JD, Hubert FX, Hurt AC, Besra GS, Porcelli S, et al. Combined NKT cell activation and influenza virus vaccination boosts memory CTL generation and protective immunity. Proc Natl Acad Sci U S A (2009) 106:3330-5. doi:10.1073/pnas.0813309106

241. Kopecky-Bromberg SA, Fraser KA, Pica N, Carnero E, Moran TM, Franck RW, et al. $\alpha$-C-galactosylceramide as an adjuvant for a live attenuated influenza virus vaccine. Vaccine (2009) 27:3766-74. doi:10.1016/j.vaccine.2009.03.090

242. Kamijuku H, Nagata Y, Jiang X, Ichinohe T, Tashiro T, Mori K, et al. Mechanism of NKT cell activation by intranasal coadministration of $\alpha$ galactosylceramide, which can induce cross-protection against influenza viruses. Mucosal Immunol (2008) 1:208-18. doi:10.1038/mi.2008.2

243. Motsinger A, Haas DW, Stanic AK, Van Kaer L, Joyce S, Unutmaz D. CD1drestricted human natural killer $T$ cells are highly susceptible to human immunodeficiency virus 1 infection. J Exp Med (2002) 195:869-79. doi:10.1084/jem. 20011712

244. Fleuridor R, Wilson B, Hou R, Landay A, Kessler H, Al-Harthi L. CD1drestricted natural killer $\mathrm{T}$ cells are potent targets for human immunodeficiency virus infection. Immunology (2003) 108:3-9. doi:10.1046/j.1365-2567.2003. 01560.x

245. Liao F, Alkhatib G, Peden KW, Sharma G, Berger EA, Farber JM. STRL33, A novel chemokine receptor-like protein, functions as a fusion cofactor for both macrophage-tropic and T cell line-tropic HIV-1. J Exp Med (1997) 185:2015-23. doi:10.1084/jem.185.11.2015

246. Deng HK, Unutmaz D, KewalRamani VN, Littman DR. Expression cloning of new receptors used by simian and human immunodeficiency viruses. Nature (1997) 388:296-300. doi:10.1038/40894

247. Loetscher M, Amara A, Oberlin E, Brass N, Legler D, Loetscher P, et al. TYMSTR, a putative chemokine receptor selectively expressed in activated $\mathrm{T}$ cells, exhibits HIV-1 coreceptor function. Curr Biol (1997) 7:652-60. doi:10. 1016/S0960-9822(06)00292-2

248. Sandberg JK, Fast NM, Palacios EH, Fennelly G, Dobroszycki J, Palumbo P, et al. Selective loss of innate $\mathrm{CD}^{+} \mathrm{V} \alpha 24$ natural killer $\mathrm{T}$ cells in human immunodeficiency virus infection. J Virol (2002) 76:7528-34. doi:10.1128/JVI. 76.15 .7528

249. Van der Vliet HJ, von Blomberg BM, Hazenberg MD, Nishi N, Otto SA, van Benthem BH, et al. Selective decrease in circulating $\mathrm{V} \alpha 24^{+} \mathrm{V} \beta 11^{+} \mathrm{NKT}$ cells during HIV type 1 infection. J Immunol (2002) 168:1490-5. doi:10.4049/ jimmunol.168.3.1490

250. Fernandez CS, Kelleher AD, Finlayson R, Godfrey DI, Kent SJ. NKT cell depletion in humans during early HIV infection. Immunol Cell Biol (2014) 92:578-90. doi:10.1038/icb.2014.25

251. Parasa VR, Selvaraj A, Sikhamani R, Raja A. Interleukins 15 and 12 in combination expand the selective loss of natural killer T cells in HIV infection in vitro. Clin Exp Med (2014) 1:3-11. doi:10.1007/s10238-014-0278-5

252. Van der Vliet HJ, van Vonderen MG, Molling JW, Bontkes HJ, Reijm M, Reiss P, et al. Cutting edge: rapid recovery of NKT cells upon institution of highly active antiretroviral therapy for HIV-1 infection. I Immunol (2006) 177:5775-8. doi:10.4049/jimmunol.177.9.5775

253. Pakker NG, Notermans DW, de Boer RJ, Roos MT, de Wolf F, Hill A, et al Biphasic kinetics of peripheral blood $\mathrm{T}$ cells after triple combination therapy in HIV-1 infection: a composite of redistribution and proliferation. Nat Med (1998) 4:208-14. doi:10.1038/nm0298-208

254. Bucy RP, Hockett RD, Derdeyn CA, Saag MS, Squires K, Sillers M, et al. Initial increase in blood CD4 ${ }^{+}$lymphocytes after HIV antiretroviral therapy reflects redistribution from lymphoid tissues. J Clin Invest (1999) 103:1391-8. doi:10.1172/JCI5863

255. Moll M, Kuylenstierna C, Gonzalez VD, Andersson SK, Bosnjak L, Sönnerborg A, et al. Severe functional impairment and elevated PD-1 expression in CD1drestricted NKT cells retained during chronic HIV-1 infection. Eur J Immunol (2009) 39:902-11. doi:10.1002/eji.200838780

256. Snyder-Cappione JE, Loo CP, Carvalho KI, Kuylenstierna C, Deeks SG, Hecht $\mathrm{FM}$, et al. Lower cytokine secretion ex vivo by natural killer $\mathrm{T}$ cells in 
HIV-infected individuals is associated with higher CD161 expression. AIDS (2009) 23:1965-70. doi:10.1097/QAD.0b013e32832b5134

257. Huang Y, Chen A, Li X, Chen Z, Zhang W, Song Y, et al. Enhancement of HIV DNA vaccine immunogenicity by the NKT cell ligand, $\alpha$-galactosylceramide. Vaccine (2008) 26:1807-16. doi:10.1016/j.vaccine.2008.02.002

258. Courtney AN, Nehete PN, Nehete BP, Thapa P, Zhou D, Sastry KJ. $\alpha$ galactosylceramide is an effective mucosal adjuvant for repeated intranasal or oral delivery of HIV peptide antigens. Vaccine (2009) 27:3335-41. doi:10.1016/ j.vaccine.2009.01.083

259. Moll M, Snyder-cappione J, Spotts G, Hecht FM, Sandberg JK, Nixon DF. Expansion of CD1d-restricted NKT cells in patients with primary HIV-1 infection treated with interleukin-2. Blood (2006) 107:3081-4. doi:10.1182/ blood-2005-09-3636

260. Snyder-Cappione JE, Nixon DF, Loo CP, Chapman JM, Meiklejohn DA, Melo FF, et al. Individuals with pulmonary tuberculosis have lower levels of circulating CD1d-restricted NKT cells. J Infect Dis (2007) 195:1361-4. doi:10. $1086 / 513567$

261. Kee SJ, Kwon YS, Park YW, Cho YN, Lee SJ, Kim TJ, et al. Dysfunction of natural killer T cells in patients with active Mycobacterium tuberculosis infection. Infect Immun (2012) 80:2100-8. doi:10.1128/IAI.06018-11

262. Bricard G, Cesson V, Devevre E, Bouzourene H, Barbey C, Rufer N, et al. Enrichment of human $\mathrm{CD}^{+}{ }^{+} \mathrm{V} \alpha 24 / \mathrm{V} \beta 11$ invariant NKT cells in intrahepatic malignant tumors. J Immunol (2009) 182:5140-51. doi:10.4049/jimmunol. 0711086

263. Tachibana T, Onodera H, Tsuruyama T, Mori A, Nagayama S, Hiai H, et al. Increased intratumor $\mathrm{V} \alpha 24$-positive natural killer $\mathrm{T}$ cells: a prognostic factor for primary colorectal carcinomas. Clin Cancer Res (2005) 11:7322-7. doi:10. 1158/1078-0432.CCR-05-0877
264. Metelitsa LS, Wu HW, Wang H, Yang Y, Warsi Z, Asgharzadeh S, et al. Natural killer $\mathrm{T}$ cells infiltrate neuroblastomas expressing the chemokine CCL2. J Exp Med (2004) 199:1213-21. doi:10.1084/jem.20031462

265. Chan AC, Neeson P, Leeansyah E, Tainton K, Quach H, Prince HM, et al. Testing the NKT cell hypothesis in lenalidomide-treated myelodysplastic syndrome patients. Leukemia (2010) 24:592-600. doi:10.1038/leu.2009.279

266. Chan AC, Neeson P, Leeansyah E, Tainton K, Quach H, Prince HM, et al. Natural killer $\mathrm{T}$ cell defects in multiple myeloma and the impact of lenalidomide therapy. Clin Exp Immunol (2014) 175:49-58. doi:10.1111/cei.12196

267. Campos RA, Szczepanik M, Itakura A, Akahira-Azuma M, Sidobre S, Kronenberg $\mathrm{M}$, et al. Cutaneous immunization rapidly activates liver invariant $\mathrm{V} \alpha 14$ NKT cells stimulating B-1 B cells to initiate T cell recruitment for elicitation of contact sensitivity. J Exp Med (2003) 198:1785-96. doi:10.1084/jem.20021562

268. Pobezinsky LA, Etzensperger R, Jeurling S, Alag A, Kadakia T, McCaughtry $\mathrm{TM}$, et al. Let-7 microRNAs target the lineage-specific transcription factor PLZF to regulate terminal NKT cell differentiation and effector function. Nat Immunol (2015) 16:517-24. doi:10.1038/ni.3146

Conflict of Interest Statement: The authors declare that the research was conducted in the absence of any commercial or financial relationships that could be construed as a potential conflict of interest.

Copyright $\odot 2015$ Slauenwhite and Johnston. This is an open-access article distributed under the terms of the Creative Commons Attribution License (CC BY). The use, distribution or reproduction in other forums is permitted, provided the original author(s) or licensor are credited and that the original publication in this journal is cited, in accordance with accepted academic practice. No use, distribution or reproduction is permitted which does not comply with these terms. 